Review

\title{
Landscape - wildfire interactions in southern Europe: Implications for landscape management
}

\author{
Francisco Moreira ${ }^{\mathrm{a}, *}$, Olga Viedma ${ }^{\mathrm{b}}$, Margarita Arianoutsou ${ }^{\mathrm{c}}$, Thomas Curt ${ }^{\mathrm{d}}$, Nikos Koutsias ${ }^{\mathrm{e}}$, \\ Eric Rigolot ${ }^{\mathrm{f}}$, Anna Barbati ${ }^{\mathrm{g}}$, Piermaria Corona ${ }^{\mathrm{g}}$, Pedro Vaz ${ }^{\mathrm{a}}$, Gavriil Xanthopoulos ${ }^{\mathrm{h}}$, Florent Mouillot ${ }^{\mathrm{i}}$, \\ Ertugrul Bilgili ${ }^{\mathrm{j}}$
}

a Centro de Ecologia Aplicada "Prof. Baeta Neves", Institute of Agronomy, Technical University of Lisbon, Tapada da Ajuda, 1349-017 Lisbon, Portugal

${ }^{\mathrm{b}}$ Department of Environmental Sciences, Universidad de Castilla-La Mancha, Avd/Carlos III, s/n, 45071 Toledo, Spain

${ }^{\mathrm{c}}$ Department of Ecology and Systematics, Faculty of Biology, University of Athens, 15784 Athens, Greece

${ }^{\mathrm{d}}$ Cemagref, UR EMAX Ecosystèmes Méditerranéens et Risques, 3275 route Cézanne, 13182 Aix en Provence, France

${ }^{\mathrm{e}}$ Department of Environmental and Natural Resources Management, University of Ioannina, G. Seferi 2, GR-30100 Agrinio, Greece

${ }^{\mathrm{f}}$ INRA, Ecologie des Forêts Méditerranéennes (UR629), Site Agroparc, Domaine Saint Paul, F-84914 Avignon cedex 9, France

${ }^{\mathrm{g}}$ Department for Innovation in Biological, Agro-Food and Forest Systems, University of Tuscia, Via S. Camillo de Lellis, snc, 01100 Viterbo, Italy

${ }^{\mathrm{h}}$ National Agricultural Research Foundation, Institute of Mediterranean Forest Ecosystems and Forest Products Technology, P.O. Box 14180,

Hymettus Avenue \& N. Chlorou 1, Ilisia, 11528 Athens, Greece

i IRD, CEFE/CNRS, 1919 Route de Mende, 34293 Montpellier Cedex 5, France

${ }^{\mathrm{j}}$ Karadeniz Technical University, Faculty of Forestry, 61080 Trabzon, Turkey

\section{A R T I C L E I N F O}

\section{Article history:}

Received 5 August 2010

Received in revised form

7 June 2011

Accepted 14 June 2011

Available online 8 July 2011

\section{Keywords:}

Fire hazard

Landscape changes

Land use/land cover changes

Land management

Mediterranean

Fire regime

Climate change

\begin{abstract}
A B S T R A C T
Every year approximately half a million hectares of land are burned by wildfires in southern Europe, causing large ecological and socio-economic impacts. Climate and land use changes in the last decades have increased fire risk and danger. In this paper we review the available scientific knowledge on the relationships between landscape and wildfires in the Mediterranean region, with a focus on its application for defining landscape management guidelines and policies that could be adopted in order to promote landscapes with lower fire hazard. The main findings are that (1) socio-economic drivers have favoured land cover changes contributing to increasing fire hazard in the last decades, (2) large wildfires are becoming more frequent, (3) increased fire frequency is promoting homogeneous landscapes covered by fire-prone shrublands; (4) landscape planning to reduce fuel loads may be successful only if fire weather conditions are not extreme. The challenges to address these problems and the policy and landscape management responses that should be adopted are discussed, along with major knowledge gaps.
\end{abstract}

(C) 2011 Elsevier Ltd. All rights reserved.

\section{Introduction}

Every year about 45000 forest fires occur in southern Europe, burning approximately 0.5 million hectares of forests and other rural lands (Camia et al., 2008). Despite the resources invested in fire prevention and suppression, the number of fires in recent

* Corresponding author. Tel.: + 35121 3653333; fax: + 351213653290.

E-mail addresses: fmoreira@isa.utl.pt (F. Moreira), Olga.Viedma@uclm.es (O Viedma), marianou@biol.uoa.gr (M. Arianoutsou), thomas.curt@cemagref.fr (T Curt), nkoutsia@cc.uoi.gr (N. Koutsias), eric.rigolot@avignon.inra.fr (E. Rigolot), barbati.sisfor@unitus.it (A. Barbati), piermaria.corona@unitus.it (P. Corona), zasvaz@gmail.com (P. Vaz), gxnrtc@fria.gr (G. Xanthopoulos), florent.mouillot@ cefe.cnrs.fr (F. Mouillot), bilgili@ktu.edu.tr (E. Bilgili). decades has continued to increase remarkably (JRC, 2005). There is growing concern about the ecological and socio-economic impacts of wildfires, particularly under a climate change context that implies an increase in the frequency and severity of wildfires in European countries in the future (e.g. Arianoutsou, 2007; Mouillot et al., 2002; Pausas, 2004; Piñol et al., 1998).

At landscape level, ignition and spread of wildfires result from a complex interaction among ignition sources, weather, topography and land cover (e.g. Mermoz et al., 2005; Rothermel, 1983). From a management perspective, land cover (related to vegetation structure and fuel loads) is the only landscape variable influencing fire behaviour that can be manipulated. Wildfires start from a local epicentre (ignition point) and spread across landscapes as a function of the abundance and arrangement of disturbance-susceptible 
patches (Forman, 1997; Turner et al., 1989). Fire spread rate can be facilitated or retarded by landscape heterogeneity (Turner and Dale, 1990). Thus, the spatial pattern of fire ignition and spread across landscapes are affected by fire proneness, i.e. the differential fire behaviour in various land cover types that are not equally fire prone (e.g. Bajocco and Ricotta, 2008; Moreira et al., 2009; Moreno et al., in press).

Understanding this link between landscape pattern and fire spread would facilitate the definition of landscape-level management rules so that Mediterranean landscapes become less fire prone. A straightforward application of this knowledge lies in the definition of landscape-scale fuel breaks, whose main objective is to reduce fuel loads or change the spatial arrangement of fuels (i.e. the landscape structure), so that when a wildfire ignites in a well managed landscape, it spreads more slowly, burns with less intensity and severity, and is less costly to suppress (e.g. Duguy et al., 2007). However, the management implications of understanding the landscape-fire relationships are not restricted to fuel break design, as they also enable the definition of land use management rules and the design and implementation of policies leading to specific landscape goals (in terms of overall fuel patterns), ranging from forest and agricultural and rural development, to urban development policies.

In this paper, we review the available scientific literature on the relationships between fires and landscape patterns and provide a critical evaluation of the scientific findings with relevant implications for landscape management. We concentrate on the geographic region covered by European Mediterranean countries where fire hazard is highest and scientific research still has important knowledge gaps. We have organised the structure of this review as a series of sections, each starting with a sentence that constitutes a key message for landscape and policy managers, and then reviewing and summarising the available scientific support. The basic structure of the approach used is shown in Fig. 1. The concluding section

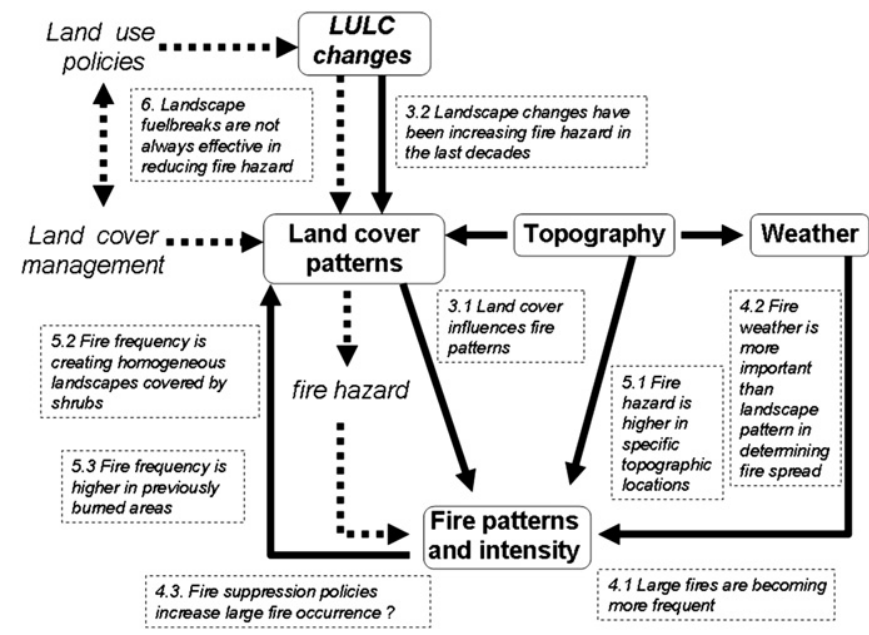

Fig. 1. Schematic overview of the approach used in the current study to address wildfire-landscape relationships in the Mediterranean region. Solid lines indicate the main drivers of fire spatial spread and intensity patterns across the landscape, whereas dashed lines show how management can influence these patterns. The key sentences addressed in the text are shown in italics. Land use/Land Cover (LULC) changes have promoted changes in land cover patterns, which influence spatial patterns of fire occurrence and fire intensity in the landscape. Both topography and weather/climate, also influence fire patterns and intensity. The landscape patterns resulting from fire cause further changes in land cover patterns. In this context, landscape management aims to promote land cover management and land use policies in order to change both the current trends in LULC and land cover patterns, so that decreased fire hazard is attained at the landscape level. The final purpose is changing fire patterns towards smaller or less severe fires. addresses overall recommendations for landscape managers, knowledge gaps, and future trends under climate change.

\section{Key concepts}

Across the text we will use the definitions of Hardy (2005) for fire risk (the chance that a fire might start) and fire hazard (a fuel complex, defined by volume, type, condition, arrangement, and location that determines the degree of ease of ignition and the resistance to control). Fire hazard expresses the potential fire behaviour for a fuel type, regardless of the fuel type's weatherinfluenced fuel moisture content (Hardy, 2005). Fire danger is commonly defined by the factors affecting the ignition, propagation, difficulty of control, and fire effects on the ecosystem (Helms, 1988). Fire weather is defined as the weather conditions which influence fire ignition, behaviour and suppression. Definition of large fire (LF), in terms of burned area, varies across the globe (Viegas, 1998) and it can be defined as the upper tail of the fire size frequency distributions (Gill and Allan, 2008). In Europe, fires above 100 ha (e.g. Bermudez et al., 2009), 500 ha (Moreno et al., 1998) or 1000 ha (Piñol et al., 1998; Viegas, 1998) are generally considered as LF. Along the paper we also use the terms fire intensity and fire severity according to Keeley (2009). Thus, fire intensity refers to the energy release during a fire, expressed as, e.g. temperature or fireline intensity. Fire severity relates to the loss or decomposition of organic matter above or below ground. It is, thus, a measure of the impact of the fire on soil and vegetation. Typical indicators of fire severity include plant mortality, the degree of tree canopy damage by a fire, or the amount of surface litter consumed.

\section{Mediterranean landscapes have increased fire hazard in the last decades: the role of land use/land cover}

Land use/land cover (LULC) changes are related to fire hazard through changes in vegetation structure and fuel load composition which, along with topography and weather, are the main drivers of fire intensity and rate of spread (Fernandes, 2009; Fernandes and Botelho, 2003; Moreira et al., 2009; Rothermel, 1983). Thus, changes in LULC are directly linked to changes in landscape fuel patterns and fire hazard (Moreira et al., 2009; Moreno et al., in press). Increased fire hazard is expected where LULC changes have promoted an increase in plant biomass (fuel load), such as those resulting from the abandonment of agricultural lands (e.g. vegetation succession in abandoned farms, pastures or woodlands) or from afforestation activities (Table 1). Conversely, other LULC changes will decrease fire hazard when associated with the removal of biomass (e.g. land clearing or forest harvesting) (Rego, 1992).

\subsection{Land cover influences fire patterns}

Studies of fire patterns in landscapes confirm the differences in fire hazard associated with different LULC. Several studies have demonstrated that shrublands are the land cover most prone to fire, i.e. with a higher proportion of area burned than expected given the availability of this land cover in the landscape, in different places of the Mediterranean basin: Spain (Diaz-Delgado et al., 2004; Gonzalez et al., 2006; Gonzalez and Pukkala, 2007; Lloret et al., 2002; Sebastian-Lopez et al., 2008), France (Mouillot et al., 2003, 2005), Portugal (Moreira et al., 2001, 2009; Nunes et al., 2005), Italy (Bajocco and Ricotta, 2008), and Greece (Koutsias et al., 2009). This can be explained by several factors, namely the lower priority given to fire fighting in shrublands (on the assumption that they are the least valuable land cover), the number of human-caused ignitions (e.g. burning for rangeland management purposes, such as creating pastures) and the higher rate of fire spread in this LULC 
Table 1

Drivers of landscape change in European Mediterranean areas, their resulting landscape patterns, and implications for fire hazard. $\uparrow=$ increase in area/fire hazard; $\downarrow=$ decrease in area/fire hazard. Larger arrows in bold indicate the predominant trend for drivers with both increase and decrease in fire hazard.

\begin{tabular}{|c|c|c|}
\hline Drivers & Landscape patterns & Fire hazard \\
\hline Decrease of farming activities & $\begin{array}{l}\text { Forests } \uparrow \\
\text { Shrublands } \uparrow \\
\text { Agricultural areas } \downarrow\end{array}$ & $\uparrow$ \\
\hline Decrease of pastoral activities & $\begin{array}{l}\text { Forests } \uparrow \\
\text { Shrublands } \uparrow \\
\text { Grasslands and pastures } \downarrow\end{array}$ & $\uparrow$ \\
\hline $\begin{array}{l}\text { Population ageing and decline/ } \\
\text { Emigration }\end{array}$ & $\begin{array}{l}\text { Forests } \uparrow \\
\text { Shrublands } \uparrow \\
\text { Agricultural areas } \downarrow\end{array}$ & $\uparrow$ \\
\hline Afforestation/reforestation & Forests $\uparrow$ & $\uparrow$ \\
\hline $\begin{array}{l}\text { Decreased exploitation of timber } \\
\text { and wood resources }\end{array}$ & $\begin{array}{l}\text { Forests } \uparrow \\
\text { Shrublands } \uparrow\end{array}$ & $\uparrow$ \\
\hline $\begin{array}{l}\text { Increase of urban, tourist } \\
\text { and industrial developments }\end{array}$ & $\begin{array}{l}\text { Forests } \downarrow \\
\text { Shrublands } \downarrow \\
\text { Urbanized areas } \uparrow\end{array}$ & $\downarrow \uparrow$ \\
\hline Increase of farming activities & $\begin{array}{l}\text { Forests } \downarrow \\
\text { Shrublands } \downarrow \\
\text { Agricultural areas } \uparrow\end{array}$ & $\downarrow$ \\
\hline Increase of pastoral activities & $\begin{array}{l}\text { Forests } \downarrow \\
\text { Shrublands } \downarrow \\
\text { Grasslands and pastures } \uparrow\end{array}$ & $\downarrow \uparrow$ \\
\hline Population increase/Immigration & $\begin{array}{l}\text { Forests } \downarrow \\
\text { Shrublands } \downarrow \\
\text { Agricultural areas } \uparrow \\
\text { Urbanized areas } \uparrow\end{array}$ & $\downarrow \uparrow$ \\
\hline
\end{tabular}

(Duguy et al., 2007; Fernandes, 2009; Moreira et al., 2009). Additionally, as a consequence of shallower soils that prevent dense forest to establish (Garcia-Fayos et al., 1995) and abandonment of hard-to-mechanize terrace cultivation (Tatoni et al., 1994), shrublands are a common land cover type in steeper slopes where the rate of fire spread is higher. On the contrary, cultivated areas (particularly those with irrigated crops) are the LULC less fire prone, burning in a lower proportion than the surface they cover in the landscape (Nunes et al., 2005; Moreira et al., 2009; Moreno et al., in press). The main reasons for the low fire-proneness of agricultural areas include their low combustibility, and their geographic association with human presence enabling quicker fire detection and easier fire fighting. Forests are usually more fire prone than agricultural areas, but less susceptible than shrublands. Within a forest context, studies in Portugal suggest that mature forests of broadleaved deciduous and mixed forests generally have a low fire hazard compared to pure pine forests, eucalypt plantations, or mixed pine and eucalyptus stands (Fernandes, 2009; Moreira et al., 2009). However, forest structure may be more important than forest composition in defining hazard (Fernandes, 2009). In fact, differences between forest types may be explained by different fuel structures, e.g. the degree of canopy closure that limits the development of a grassy or shrubby fuel bed and maintains vegetation with high moisture content (Gracia et al., 2002; Pausas et al., 2008; Vazquez et al., 2002; Zavala et al., 2000). There is some evidence that mature evergreen oak forests can even become 'self-protective' against wildfires, to the point of fire self-extinction (Fernandes et al., 2010).

In addition to landscape composition, landscape configuration also has strong implications for fire hazard. For example, the spatial patterns formed after the abandonment of rural areas have created landscapes of high combustibility through increasing significantly the availability and contiguity of fuel loads (e.g. Mazzoleni et al., 2004; Sluiter and de Jong, 2007; Saglam et al., 2008). Some studies have confirmed that fire hazard was greater in the more contiguous and homogeneous landscape portions (Lloret et al., 2002; Vega-García and Chuvieco, 2006). Other studies applied fire resistance rules to LULC types at the scale of fire events (Viedma et al., 2009) or at both stand and landscape scales (Gonzalez et al., 2005,2008 ) and showed that landscape resistance to fire was negatively influenced by the spatial contiguity of LULC, and positively influenced by the diversity resulting from fuel contrast at fire edges. Simulation models also showed that fire spread and behaviour were greatly influenced by the spatial distribution of fuels (Duguy et al., 2007).

\subsection{Landscape changes have been increasing fire hazard in the last decades}

Studies of LULC changes in the Mediterranean Europe typically have a time span of 30-50 years, since the 1950's (coinciding with the first available aerial photographs) to the beginning of the XXI century, although there are exceptions, e.g. Preiss et al. (1997; ca. 15 years) and Mouillot et al. (2005; more than 200 years). The usual extension of a study area is $3000-5000$ ha, but is also highly variable, e.g. 40 ha in Baudry and Tatoni (1993) to the whole of Italy (Falcucci et al., 2007). Aerial photographs, satellite images and land use or land cover maps have been the most common sources of data used.

A large number of studies have provided evidence of increased fire hazard in Mediterranean rural areas, mainly due to the increased cover of forests and shrublands in areas with former lower fuel loads and fire hazard (e.g. agricultural or pastoral land) (Table 1). For example, Van Doorn and Bakker (2007), in a region of southern Portugal, registered a $75 \%$ decline in the area of agricultural fields during the period 1985-2000, and an increase in matorral (shrubland) and forest plantations. Falcucci et al. (2007), for the whole of Italy, measured a $74 \%$ increase in forest cover during the period $1960-2000$, and a $20 \%$ decrease in agricultural areas.

Several other studies have shown similar patterns of change across different countries: Portugal (Moreira et al., 2001; Moreira and Russo, 2007), Spain (Lloret et al., 2002; Pérez et al., 2003; Romero-Calcerrada and Perry, 2004; Viedma et al., 2006; VegaGarcía and Chuvieco, 2006; Duguy et al., 2007; Hill et al., 2008; Olarieta et al., 2008), France (Debussche et al., 1999; Taillefumier and Piégay, 2003; Mouillot et al., 2005), Italy (Peroni et al., 2000), Greece (Papanastasis et al., 2004) and Israel (Carmel and Kadmon, 1999), among others.

Agricultural land abandonment, including the decline of pastoral activities, is the major driver of landscape changes and increased fire hazard (Table 1), mainly in mountainous areas (Acosta et al., 2005; Aranzabal et al., 2008; Falcucci et al., 2007; MacDonald et al., 2000; Papanastasis et al., 2004). This abandonment is caused by the low economic profitability of these areas and is often associated with ageing, emigration and rural population declines. Marginal agricultural land, often located in steeper slopes, is the first to be abandoned (e.g. Peroni et al., 2000; Sluiter and de Jong, 2007; Van Doorn and Bakker, 2007). Vegetation succession then leads to scrub encroachment and forest development (e.g. Arianoutsou, 2001; Carmel and Kadmon, 1999; Scozzafava and De Sanctis, 2006). Even if farming activities do not disappear completely, the abandonment of traditional practices of exploitation of timber and wood resources (Debussche et al., 1999; Moreira et al., 2001) contribute to increasing fire hazard. Reforestations and afforestations, which have been promoted in the Mediterranean region in the last decades, both under the scope of forest policies (e.g. Pausas et al., 2004a), or, more recently, as a policy-driven management alternative in abandoned agricultural land (e.g. 
MacDonald et al., 2000; Pausas et al., 2004a), have achieved certain environmental goals (i.e. to increase carbon sink capacity or to stop desertification processes), but have also increased fire hazard when creating large areas with homogeneous even-aged stands of flammable species (cf. § 3.1).

In contrast to the general trend, only a small proportion of the studies, mainly located in coastal areas, provided evidence of decreased fire hazard coupled with the loss of forest and shrubland cover. For example, Serra et al. (2008) described increased agricultural activities and urbanization in a coastal region of southern Spain. Similar patterns were described for coastal areas in Turkey (Alphan and Yilmaz, 2005), Lebanon (Jomaa et al., 2008) and Italy (Corona et al., 2007; Falcucci et al., 2007). These changes have been driven by developments in urbanization, tourism and industry, increases in population and intensification of agricultural practices (e.g. Serra et al., 2008; Tanrivermis, 2003; Van Eetvelde and Antrop, 2004), including livestock grazing (e.g. Lyrintzis, 1996).

Depending on the social context in specific regions, some drivers may have a dual effect on fire hazard (Table 1 ). For example, LULC changes reflected in a hypothetically lowered fire hazard, because of biomass removal, may in fact increase fire risk. These include a more intensive use of pastures associated with an increasing use of fire for pasture renewal (Arianoutsou, 1998; Bajocco and Ricotta, 2008; Martinez et al., 2009; Mouillot et al., 2003), or an increased wildland-urban interface due to urban sprawl (e.g. Arianoutsou, 2001; Curt and Delcros, 2010; Martinez et al., 2009; RomeroCalcerrada et al., 2010; Wittenberg and Malkinson, 2009; Vasconcelos et al., 2001; Vazquez et al., 2002). In fact, population density and distance to roads are the major drivers of ignition risk and recent fire research studies identified the rural-urban interface as the most fire prone areas in Mediterranean countries (BadiaPerpinya and Pallares-Barbera, 2006; Catry et al., 2009; Curt and Delcros, 2010; Moreira et al., 2009).

In summary, most observed landscape changes can be described by what Hill et al. (2008) called the "rural exodus syndrome", the widespread increase in vegetation biomass over wide areas of southern Europe and the "strong urbanization tendencies and concentration of population along the coasts and in major cities, contrasting with decreasing population in the hinterlands". This seems to be the main trend across all the European Mediterranean countries, causing increased fire hazard except near the coast and in specific locations where tourism, intensification of agriculture and urban development prevail (Hill et al., 2008; Mazzoleni et al., 2004). This overall trend in southern Europe strongly contrasts with that observed in Mediterranean North African countries, where deforestation as a result of grazing, clearing for agriculture, woodcutting for heating and charcoal production (Mazzoleni et al., 2004), coupled with increasing population, contribute to decreasing fire hazard.

\section{Large fires are becoming more common in the Mediterranean region: the role of weather, landscape patterns and fire suppression policies}

\subsection{Large fires are becoming more frequent}

Large fires (LF) are relatively new in the recent history of the Mediterranean Basin (Lloret and Marí, 2001). Recent exceptional fire seasons (e.g. 1978/79 and 1994 in Spain, 1998, 2000 and 2007 in Greece, 2005 in Portugal, 2003 throughout Europe) helped to highlight the importance of LF in the Euro-Mediterranean (e.g. Oliveras et al., 2009; Piñol et al., 1998; Pausas, 2004; Xanthopoulos, 2007a). LFs represent a small fraction of the total number of fires, but are responsible for a large percentage of the total land area burned in the Mediterranean basin (e.g. Bermudez et al., 2009;
Diaz-Delgado et al., 2004). They tend to occur under specific, relatively uncommon synoptic meteorological conditions (like high temperatures, prolonged drought and strong winds), have different behaviour (e.g. higher intensities), have different patterns and spread mechanisms, a lower range of suppression options, and, depending on their rate of recurrence as well as landscape-scale variation in severity, more adverse ecological effects (Bermudez et al., 2009; Diaz-Delgado and Pons, 2001; Gill and Allan, 2008; Pausas et al., 2008; Romme et al., 1998).

Although some studies reported an increase of LF occurrence in Spain during the last decades (Diaz-Delgado et al., 2004; Moreno et al., 1998), others found no evidence of increasing or decreasing trends over time in Portugal (Bermudez et al., 2009), in France (Amouric, 1992) or at the European scale during a period of ca. 20 years (San-Miguel and Camia, 2009), suggesting that regional trends could be quite variable. For example, Bermudez et al. (2009) analysed the occurrence of LF in Portugal during a period of 21 years and found a cyclical pattern of occurrence of extreme fire sizes, with a return period of $3-5$ years, and argued that this might result from post-fire recovery response of vegetation (i. e. rates of fuel accumulation), more than meteorological or anthropogenic factors. On the contrary, Pausas and Fernandez-Muñoz (in press) showed a large increase in LF occurrence in the 1973-2006 period in Valencia region (Spain), in relation to the 1873-1972 period.

In summary, although the number of fires and total burned area has increased in southern Europe, a clear trend of increasing occurrence of LF is not always the rule, as there is wide geographic variability. However, existing evidence does suggest an increase in LF frequency in several regions, either monotonically or in a cyclic pattern.

\subsection{Fire weather is more important than landscape pattern in determining fire spread}

There is still a debate on whether landscape pattern or meteorological conditions are the fundamental controller of fire spread, or whether temperature alone can explain recent and forecasted trends in fire occurrence in the Mediterranean basin (Piñol et al., 2005). While in some areas, such as in the boreal forest, it appears that landscape plays a less important role in determining what is burned by fires (Podur and Martell, 2009), in the Mediterranean region, selectivity by fire towards certain LULC types show that the landscape plays a more critical role in fire spread (e.g. Bajocco and Ricotta, 2008; Moreira et al., 2001, 2009; Moreno et al., in press).

Overall, inter annual variability in burned areas is closely linked with annual climate indices of drought, temperature or a combination of both. This has been shown from recent global remote sensing studies (Van der Werf et al., 2003) and used in global fire models (Thonicke et al., 2001). In the Mediterranean, these indices remain valid at the landscape (Mouillot et al., 2003) and regional levels (Pausas, 2004; Pereira et al., 2005; Vazquez and Moreno, 1993; Viegas and Viegas, 1994) with as simple indices as summer rainfall explaining a significant proportion of annual variability in total area burned. For example, in Cantabria (north Spain), most fires occur in conjunction with "Suradas", a weather event which combines high winds and low humidity, resulting in high-risk situations (Carracedo et al., 2006). Extreme fire weather may further promote the occurrence of fire brands and spot fires, leading to indirect climate-related extreme fire events in terms of area burned. In the Mediterranean region, people-ignited fires are largely predominant over natural ignitions, but Vazquez and Moreno (1998) showed that the number of lightning fires is also increasing, and this cause was associated to some of the largest 
recorded fires (Moreno et al., 1998; Vazquez and Moreno, 1998). Thus, LF occurrence can be favoured by an increase in naturally caused ignitions, eventually even being influenced by solar activity (Gomes and Radovanovic, 2008).

In spite of the trend for the total area burned being correlated with climate, there is scarce evidence that average (or maximum) fire size increases with harsher fire weather conditions (e.g. Piñol et al. (1998) in Spain and Good et al. (2008) in Italy and Greece). Some studies do not even show a relationship between climate and fire occurrence (Fule et al., 2008; Wittenberg and Malkinson, 2009), confirming that other processes are also involved in fire ignition and spread.

Currently, the relative contribution of weather versus landscape pattern on fire spread in Mediterranean landscapes may be related to thresholds in fire weather that allow (or not) the landscape pattern to arise as a driver enhancing or, in particular, inhibiting fire spread. Under moderate fire spread conditions, fires tend to be smaller, and fuel spatial patterns would exert a stronger control on fire spread. Thus a higher selectivity towards flammable fuels would be expected. Extreme fire weather could produce large wildfires whose spread is not determined by landscape structure (Salvador et al., 2005; Moritz et al., 2010). In the past the situation may have been different. In a recent study, Pausas and FernandezMuñoz (in press) suggested that fire regime changes in the western Mediterranean were different before the 1970s, where fires were mostly fuel-limited, from the present, where they are mostly drought-driven.

\subsection{Fire suppression policies increase large fire occurrence?}

Fire suppression policies can also lead to fuel accumulation and LF outbreaks (e.g. Oliveras and Piñol, 2006). Piñol et al. (2005) used a model of vegetation dynamics and fire spread, calibrated with real data from 2 areas in the Iberian Peninsula, to evaluate the effect of different fire fighting capacities on LF occurrence. Interestingly, their simulations showed that higher fire-fighting capacities, or a lower number of ignitions, resulted in the same total annual area burned but with a higher proportion of LF. In fact, the reinforced funds on fire suppression policies observed in Mediterranean countries (especially after disastrous fire seasons), if not combined with fuel management, seem to be effective at reducing small fires, but not large ones (Diaz-Delgado et al., 2004; Duguy et al., 2007; Gonzalez and Pukkala, 2007; Xanthopoulos, 2007b, 2008a). Events in Greece since the dramatic fire season of 2000 are a good example for this. As warned by some (e.g. Xanthopoulos, 1998, 2007c), a strong fire suppression policy implemented in the 2001-2006 period, that temporarily appeared to be successful, did not solve the country's fire problem. In 2007 Greece experienced its worst fire season ever, with fires exceeding 20000-30000 ha mainly as a result of fuel accumulation.

\section{Higher fire frequency in specific topographic locations and previously burned areas is creating homogeneous landscapes covered by shrublands}

Contrary to what could be expected from the fuel-age paradigm, which states that fuel reduction as a consequence of wildfires would reduce the risk of future fires (Zedler and Seiger, 2000), there is evidence that areas previously burned are characterized by a higher probability to burn when compared to areas that were never burned. So, it seems that previous fires determine conditions that favour a new fire in a relatively short time period. The repeated burning phenomenon might be interpreted as a result of several spatial legacies influencing fire occurrence, nested within each other, and resulting in a strong spatial dependence of fire on previously burned areas. The mechanisms that might contribute to and the consequences of repeated burning are summarised below.

\subsection{Fire hazard is higher in specific topographic locations}

Topography (altitude, exposure, slope) can affect fire frequency and rate of spread. The causes behind these topographic effects can be grouped into fire ignition patterns, fire behaviour (in particular rate of spread), and fuel biomass. Disentangling these processes is not easy, as they are interrelated and dependent on the spatial scale (i.e. grain and extent). In fact, topography interacts with local wind direction, microclimates and, in turn, vegetation type, fuel loads and moisture content. Several studies have shown topographic influences on vegetation composition and structure (Fontaine et al., 2007; Rescia et al., 1994), transpiration and desiccation conditions (Rana et al., 2005; Van der Trol et al., 2007), vegetation dynamics (Carmel and Flather, 2004; Mouillot et al., 2005), fire severity (Broncano and Retana, 2004), and post-fire vegetation regeneration (Peñuelas et al., 2007; Baeza et al., 2007). Furthermore, some of the observed topographic effects on fire occurrence can be explained by human activities (e.g. Carmo et al., 2011; Catry et al., 2009; De la Cueva et al., 2006; Martinez et al., 2009; Romero-Calcerrada et al., 2010; Salvador et al., 2005). As an example, in some regions higher probabilities of ignitions have been estimated at higher altitudes, because of a higher likelihood of lighting and human use of fire for the management of pastures for livestock (Catry et al., 2009; Kilinc and Beringer, 2007; Price and Rind, 1994; Vazquez and Moreno, 1998). In other locations, high ignition risk is associated with flat and lower elevated areas because of the proximity to roads, human settlements and urban interfaces (Vasconcelos et al., 2001).

As a result, several studies have provided evidence of significant spatial pattern of fire recurrence associated with certain topographic positions across the Mediterranean region. For example, Mouillot et al. (2003) found that south facing slopes and ridge crests burned more frequently than other positions in Corsica (France). Similar patterns were observed by Vazquez and Moreno (2001) in Spain, and Trabaud and Galtié (1996) in the French Pyrenees. Fire spread simulation models, such as FARSITE (Finney, 1998), and FIRETEC, recently applied for Mediterranean landscapes in Italy (Arca et al., 2007), middle East (Carmel et al., 2009), Spain (Duguy et al., 2007) and France (Pimont et al., 2009) have highlighted the intrinsic preference for fire spread towards certain topo-climates as high altitudes and uphill directions where local winds, usually blowing towards the ridge top in the daytime, enhanced the topographical effect (Boboulos and Purvis, 2009).

\subsection{Fire frequency is creating homogeneous areas covered by shrublands}

Some pine forests have a low resilience to increased fire frequency. For example, Pinus halepensis and Pinus pinaster forests in eastern and Central Spain show very low resilience when burned frequently, turning into shrublands in the medium to long term after fire (e.g. Baeza et al., 2007; Pausas et al., 2008). The same was shown by Arianoutsou et al. (2002) for P. halepensis forests in central Greece. The reason behind this shift is related to the characteristics of the reproductive biology of these pines (Arianoutsou, 1998). $P$. halepensis individuals reach their full reproductive capacity when $15-20$ years old by having a canopy seed bank in their serotinous cones. Hence, when a fire occurs over a previously burned pine stand with a return interval shorter than this time window, pines will not regenerate and the structure of vegetation communities is changed to one dominated by grasses and shrubs (Eugenio et al., 2006; Kazanis and Arianoutsou, 2004; Kazanis et al., 
2007, 2009; Lloret et al., 2003) (Fig. 2). A similar pattern should be expected for Pinus brutia forests.

Other fire-sensitive pine species as Pinus nigra and Pinus sylvestris which are not serotinous, do not have any specific adaptation to cope with fire and their recovery is mainly dependent upon the seed dispersal from unburned patches (Arianoutsou et al., 2010; Buhk et al., 2007; Eugenio and Lloret, 2004; Eugenio et al., 2006; Retana et al., 2002; Rodrigo et al., 2004, 2007). In the case of some deciduous oak communities, the recovery process after fire is very low, and more than 50-60 years are needed to reach the prefire conditions (Calvo et al., 2002a,b; Jacquet and Prodon, 2009). During the initial stages (0-20 years) homogeneous shrubland communities dominate spatially and influence negatively the growth of Quercus pyrenaica (Alvarez et al., 2009; Calvo et al., 2002a,b). Hence, short fire intervals could favour the expansion of shrublands communities or the persistence of resprouting oak forests with a shrubland-type physiognomy (Fig. 2). Even for some evergreen oaks (as Quercus suber and Quercus ilex) that show vigourous resprouting after fire and a quick recovery (Debussche et al., 2001; Espelta et al., 2003), high fire frequencies may decrease such ability (Diaz-Delgado et al., 2002; Trabaud and Galtié, 1996). Finally, in burned old croplands post-fire succession is mostly limited to obligate-seeders, a process that has resulted in the spread of Mediterranean gorse shrublands (Ulex parviflorus) in some areas, increasing the risk and severity of fires (Baeza et al., 2007) (Fig. 2).

\subsection{Fire frequency is higher in previously burned areas}

Several authors have documented high fire recurrence in previous burned areas across several Mediterranean countries. For example, in central Corsica (France), some areas were burned up to 7 times from 1957 to 1997 (Mouillot et al., 2003). In Catalonia (Spain), ca. 12\% of the total areas burned during 1975-1998 burned twice during this period (Diaz-Delgado et al., 2004). In an area of Central Spain, the forests that burned twice in the years 1970-1990 accounted for about the $7 \%$ of the total forest area burned (Vazquez and Moreno, 2001). In Italy, 60\% of the forest fires in the period 2005-2009 occurred in areas that had been burned in the past ten years (CFS, 2005, 2006, 2007, 2008, 2009).

As was mentioned in the previous section, one first explanation for the increased fire recurrence is the low resilience of some forest types, which prevents auto-succession and favours the establishment of more fire-prone fuel types (Acácio et al., 2009; Lloret et al.,

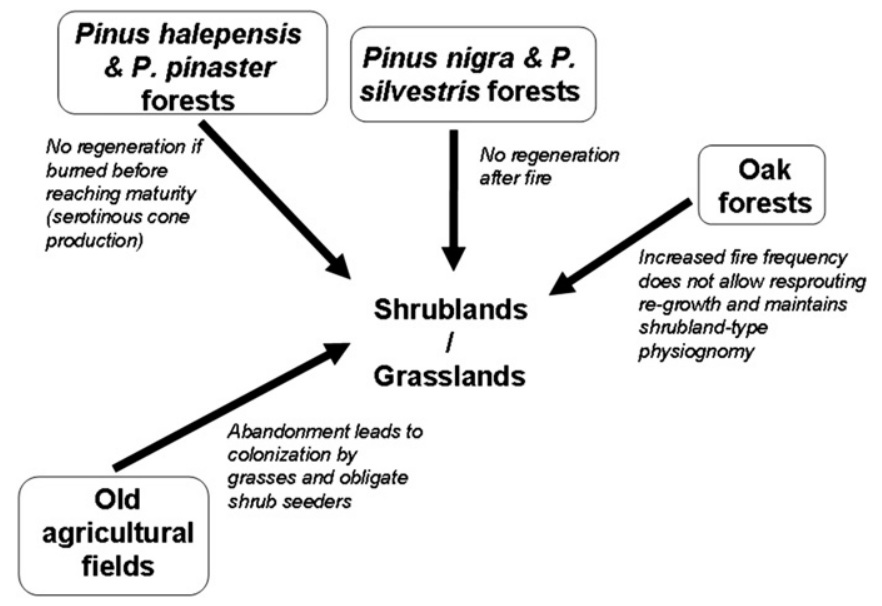

Fig. 2. Summary of processes leading to the replacement of forests and agricultural land by shrublands and grasslands in Mediterranean landscapes with high fire frequency. For further explanations, see text.
2002, 2003; Pérez and Moreno, 1998) (Fig. 3). Another explanation is that surface fuel loads recover very quickly after fire, often exceeding pre-fire amounts. For example, in non-salvaged burned forests, hazardous fuel production is a function of the decay and fall of fire-killed snags driving accumulation of both coarse and fine woody debris (Keyser et al., 2009). In other burned areas, highly flammable tussock grasses (some of which are alien) can replace locally dominating woody species, resulting in increasing frequencies of very large and intense fires (Grigulis et al., 2005; Vilà et al., 2001). Several studies have confirmed that the recovery rate of scrub cover after fire was quite rapid, often exceeding the pre-fire biomass amount (Hernandez-Clemente et al., 2009; Roder et al., 2008; Viedma et al., 1997). Simulation models such as FATELAND and BROLLA have shown an increase in shrublands as a response to increased fire frequency, creating a state of successional stagnation which may enhance the positive shrub-fire feedback (Pausas, 1999; Pausas and Lloret, 2007) (Fig. 3).

Thirdly, fire disturbance creates more connected and homogeneous vegetation patches (fuel continuity) that favours fire spread and future fires (Chuvieco, 1999; Lloret et al., 2002; Loepfe et al., 2010; van Leeuwen et al., 2010; Viedma et al., 2006). Shrublands form large patches of fuel of the same age because the post-fire fuel build-up is rapid (Baeza and Vallejo, 2008). Furthermore, spatial patterning of fire severity and associated fire-induced vegetation mortality can increase the amount and continuity of dead fuels contributing to reburning (Collins et al., 2007). However, it is also recognized that variations in fire severity can enhance landscape heterogeneity, creating patches with different successional stages (Lloret et al., 2002; Pérez et al., 2003; Trabaud and Galtié, 1996) and unburned patches within fire scar perimeters (Koutsias and Karteris, 1998) that can alter the probability of reburning. In general, the effects of fire on landscape may vary from region to region because of differences in local fire history, regeneration patterns among main land covers and topographic constraints (Viedma, 2008). Finally, people's perception of the low value of burned areas reinforces these positive feedbacks leading to increased fire frequencies (Blasi et al., 2004; Vazquez and Moreno, 2001). There is a social perception that burned areas are less valuable which, in the absence of proper conservation strategies, makes them more prone to land abandonment or misuse (e.g. grazing, pastoral burning) with the effects already discussed. This might potentially lead frequently burned areas to a spiral towards deforestation (Arianoutsou, 1985) that will, in turn, create shrub-dominated landscapes with higher fire risk (Espelta et al., 2008) (Fig. 3).

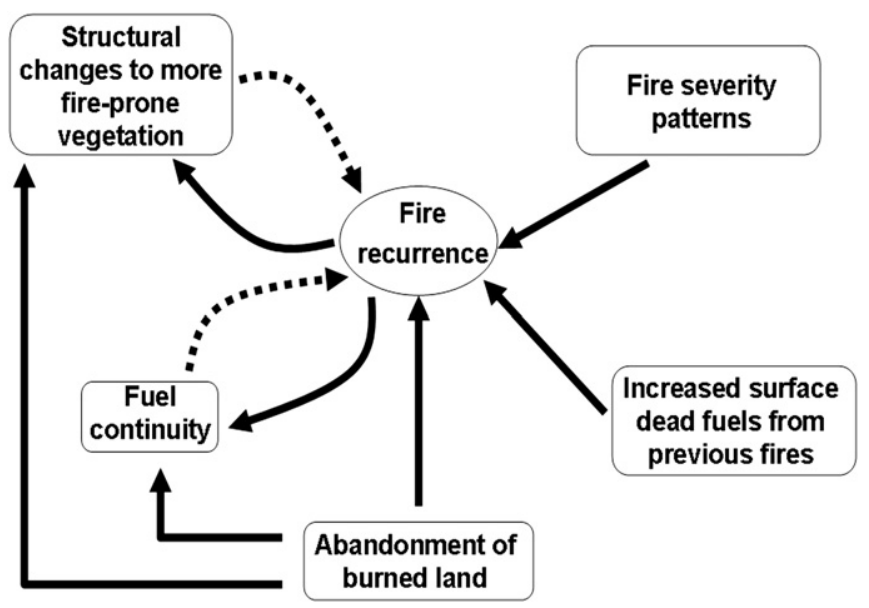

Fig. 3. Possible (feedback) mechanisms through which increasing fire recurrence may occur in Mediterranean landscapes. For further explanations, see text. 


\section{Landscape fuel breaks are not always effective tools to reduce fire hazard under extreme weather conditions}

\subsection{Fuel management strategies}

Fuel management can be implemented using three main strategies, respectively isolation by fuel breaks, area-wide fuel modification and fuel type conversion (Rigolot et al., 2009). The isolation by fuel break strategy has been the most used, and involves compartmentalising large areas of fire prone fuel types with a network of strips where fuel has been manipulated with the objective of helping fire fighters to (i) break up the continuity of hazardous fuels across a landscape; (ii) reduce the intensity of wildfires, providing broad zones within which fire-fighters can conduct suppression operations more safely and efficiently; (iii) provide strips to facilitate subsequent area-wide fuel treatments; and (iv) provide various non-fire-related benefits (e.g. habitat diversity, landscape scenery) (Agee et al., 2000; Cumming, 2001; Rigolot, 2002; Weatherspoon and Skinner, 1996). This strategy has been implemented in southern Europe in the last decades, mainly in France, Portugal, and Spain, and to a lesser extent in Italy and Greece and Turkey (Bilgili, 1998; Xanthopoulos et al., 2006).

Area-wide fuel modifications are an extensive application of fuel treatments at the forest stand level that include reduction of fuel load, increased fuel compactness and disruption of vertical and horizontal fuel continuity (Chandler et al., 1983). Although it is much less strategically planned than fuel break networks, it may complement it by working inside the landscape units isolated by the fuel break network. The patchy pattern of fuel treatments creates a landscape mosaic that increase its resistance to fire spread by the limitation of ladder fuels (Vélez, 1990, 2000).

Fuel type conversion involves replacing highly flammable vegetation by low growing, less hazardous species (Rigolot et al., 2009). Real fuel type conversion towards fire resistant vegetation is mostly limited to wildland-urban interfaces where landowners can choose less flammable ornamental (preferably native) species. In wildland areas, natural succession can be used where site conditions enable it to promote a mixture of species and to favour mature stages (Vélez, 1990). This naturally slow process can be somewhat speeded up with some selective thinning favouring broadleaved species.

\subsection{Assessing fuel break effectiveness}

Duché and Rigolot (2000) distinguish three main objectives for fuel breaks: (i) to decrease fire ignition events, (ii) to decrease total burned area and (iii) to decrease fire effects on people, human resources and ecosystems. Thus, fuel break design and evaluation of effectiveness will differ depending on the objectives. Clearly, the effectiveness of fuel management in general and of landscape fuel breaks in particular can not be solely assessed by fire size reduction and effective fire suppression, but it should also take into account the benefits for fire suppression actions and the reduction of the environmental and the socio-economical impact of wildfires.

Several approaches have been used for assessing the effectiveness of fuel control techniques for fire hazard reduction (e.g. Fernandes and Botelho, 2003) or for decreasing wildfire intensity and severity (Rigolot, 2002). The expert appraisement approach uses the experience of highly skilled fire professionals to provide standards for fuel break building and maintenance based on the best knowledge and practices (Rigolot and Morvan, 2003). Experimental fires can be used to test the probability of fuel break crossing, depending on fire intensity (Davidson, 1988) or to assess fuel-break dimensions (Wilson, 1988). The experimental approach is risky and it is almost impossible to test the highest part of fire intensity scale (Davis, 1965). Computer simulations using fire behaviour or fire growth models have been successfully used for assessing the effectiveness of silvicultural and fuel treatment scenarios (Duguy et al., 2007). Finally, analysing in the field situations where fuel breaks have been hit by wildfires strongly contributes to an efficient fuel-break design (Lambert et al., 1999; Rigolot and Alexandrian, 2006).

Field studies devoted to assessing the effectiveness of fuel breaks in controlling fire size have been carried out in south eastern France during 1993-2003 (Lambert et al., 1999; Perchat and Rigolot, 2005; Rigolot and Alexandrian, 2006). On the whole, 28 fuel breaks have been analysed including a large variety of situations (topographic situation, width, vegetation types, weather conditions, alignment of fuel break with fire front). The difficulties met by suppression forces to arrive and fight the fire in the fuel break network, as well as the ability of homogeneous fuel break segments in containing fire were assessed. In all these studies, the key factors of fuel breaks success were the quality of fuel break design and maintenance, early fire detection and good knowledge of the fuel break network by firefighters. Factors of failure were late arrival of suppression forces and fuel break discontinuities due to legal restrictions on fuel management or weak points due to topographic or fuel control difficulties. Under extreme fire weather conditions (e.g. the 2003 fire season), fuel breaks perpendicular to fire propagation could never contain the fire front and were crossed over by surface fires in the absence of ground suppression forces and by heavy fire spotting. On the contrary, flank fuel breaks could systematically limit the lateral extension of wildfires, even under extreme fire conditions. But in general, fuel break design and maintenance standards (RCC, 2002) were effective for moderate to severe fire weather conditions, providing suppression forces were present on the spot.

The case studies approach is constrained by the low number of fires versus fuel break situations encountered and limited data available to analyse them. The simulation approach enables to broaden the range of possible situations and to test innovative fuel break designs. Analyses from simulation models, (e.g. the physically-based fire propagation model FIRETEC) assessed the impact of fuel break vegetation structure on fire behaviour (Dupuy, 2009). Using the same model, Pimont et al. (2006, 2009) explored the effect of tree layer cover in the likelihood of crowning fire and fire rate of spread. At landscape management scale, and using the spatially explicit fire growth model FARSITE, Duguy et al. (2007) showed that different fuel scenarios may be successful in relation to fire size control: the fragmentation of a fire prone matrix with patches in different successional stages, the introduction of narrow corridors between wooded patches and the promotion of convoluted perimeters were effective in reducing fire size. In some northern Mediterranean regions, the local administration is using FARSITE as a tool for predicting consequences of fuel management options on fire growth (Duguy et al., 2007).

\section{Concluding remarks: landscape management and policy implications}

The main implications of the findings from scientific research for policy and landscape management are summarised in Table 2. We have identified four main challenges to address, that need specific landscape management and policy guidelines.

\subsection{Reverse the detrimental implications of land cover changes and manage LULC to reduce fire hazard}

Population decline, agricultural and pastoral land abandonment (and the subsequent natural regeneration of forests), and policies promoting forest cover, particularly in former agricultural land, are 
Table 2

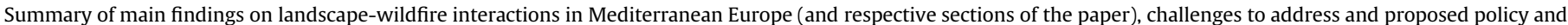
landscape management responses.

\begin{tabular}{ll}
\hline Main findings & Challenges to address \\
\hline Land cover changes are & Reversing the detrimental implications \\
increasing fire hazard & of land cover changes \\
(Section 3) & Managing land use and land cover to \\
& reduce fire hazard
\end{tabular}
Large fires are becoming
more frequent (Section 4)

Frequent fires are creating homogeneous landscapes covered with shrublands which are more fire prone (Section 5)
Being prepared for large fires and aim at reduced damage, rather than reduced area burned

Increase landscape heterogeneity and decrease the probability of repeated burning
Policy/Landscape management responses

$\sqrt{ }$ Implement policies to reverse population decline in mountain areas;

$\sqrt{ }$ Promote agricultural and pastoral activities, particularly in mountain regions;

$\checkmark$ Promote farming practices in areas surrounding villages, and enforce existing laws on fuel management around buildings and villages;

$\checkmark$ Stop afforestation policies in high fire hazard areas;

$\sqrt{ }$ Reduce fuel accumulation through prescribed/pastoral burning;

$\checkmark$ Explore potential for biofuels as a tool to remove fuels from the landscape;

$\checkmark$ Forest planning should give preference to deciduous broadleaved and mixed forests, rather than pine plantations;

$\sqrt{ }$ Invest more in prevention (fuel management) rather than suppression policies;

$\sqrt{ }$ Focus on reducing fire intensity and potential damage, rather than trying to control fire size, specially under extreme fire weather conditions;

$\sqrt{ }$ Reduce vulnerability of values at risk (landscape planning at the rural-urban interface, fuel management around buildings and villages);

$\checkmark$ Educate citizens on fire-response planning (defence and evacuation);

$\checkmark$ In landscape planning take into account that specific topographic locations (e.g. steeper slopes, ridge crests, south exposures) may have greater fire hazard;

$\sqrt{ }$ Promote landscape heterogeneity, by planning land covers with alternate higher and low fire hazard;

$\checkmark$ In forested areas, plan forest management to spatially alternate stands with different ages/fuel types

$\checkmark$ Implement policies for the wise use of fire in pastoral burnings;

$\sqrt{ }$ Increase fire prevention measures in forests that have no post-fire regeneration ability (e.g. in immature Pinus halepensis and

$P$. pinaster forests, and in vulnerable $P$. nigra and $P$. sylvestris forests);

$\checkmark$ Increase fire prevention in growing oak forests, that take longer to recover;

$\sqrt{ }$ Under normal fire weather conditions, promote fuel management to extend fire suppression options and effectiveness;

$\checkmark$ Under extreme fire weather, focus on reducing fire intensity and damage through self-protection;

$\checkmark$ Plan fuel isolation options at the landscape level, combined with area-wide fuel modifications;

$\sqrt{ }$ Use the whole range of fuel management techniques, including silviculture, agricultural and pastoral management, and the use of fire, as a tool; driving the "rural exodus syndrome" (Hill et al., 2008) and causing a widespread increase in vegetation biomass over large areas of the Mediterranean Europe, mainly in mountain areas, and a subsequent increase in fire hazard. This trend can only be counteracted effectively through the creation of policies enabling the improvement of the socio-economic conditions of people living in rural areas, promoting new immigration to these regions, and implementing rural development policies that foster activities contributing to reducing fire hazard, such as agriculture and livestock grazing. These policies are mainly related to agricultural, rural development and economic issues, rather than forest management. For example, the European Agriculture Fund for Rural Development (EAFRD) (EC 1698/2005 of 20 September 2005) could contribute to achieve these objectives in disadvantaged rural areas by: a) improving the competitiveness of agriculture and forestry activities; (b) improving the quality of life by the diversification of economic activity, and c) supporting land management strategies.

In relation to land management strategies, there is conclusive evidence that agricultural areas are the least fire-prone LULC, whereas shrublands are particularly fire prone. This general pattern highlights the relationships between agricultural abandonment and fire hazard in the Mediterranean, as the land-cover types more avoided by fire (agricultural crops) are progressively replaced, in many cases, by the most fire-prone land cover type (shrublands).
So, there is a need to define policies to maintain farming activities in areas where landscape planning identified as priority sites for fuel reduction, such as areas surrounding villages or pastoral activities in landscape fuel breaks. In fact, one of the most serious consequences of the abandonment of traditional practices is that villages in mountain areas, traditionally surrounded by a belt of farmland that acted as a landscape fuel break, nowadays have forests and shrublands in the vicinity of houses and other infrastructures, which greatly increase fire hazard. Agro-environmental activities should continue to play a prominent role in supporting the sustainable development of rural areas and in responding to society's increasing demand for environmental services. In general, there is a need for reinforcement of the existing laws and regulations on fuel management around buildings and villages, either through farming or other types of fuel reduction techniques.

Prescribed fire or controlled pastoral fire, or energy policies supporting the environmentally compatible use of renewable bioenergy potential from agriculture and forestry (agricultural waste, crop mix for biomass production, complementary fellings and residues from silvicultural activities and/or fuel management) may also contribute to reducing fire hazard, while providing job opportunities to rural populations. Appropriate use of fire by rural communities coupled with the development of prescribed burning undertaken by fire professionals may be used in integrated fire 
management (Silva et al., 2010). In the Mediterranean countries, traditional use of fire is associated with rangeland management and other rural activities like burning agro-forestry remains and game management. When not used under legal regulation and good practices, traditional use of fire may be a significant cause of wildfires (Xanthopoulos et al., 2006). On the other hand, in some regions good practices in traditional burning should be maintained and this activity needs to be recognized, consolidated and regulated as part of a community based fire management approach (Silva et al., 2010). Under this new framework, traditional burning may fully contribute to fuel management at the landscape level (Rego et al., 2010b). Recent studies have shown the possible renewal of active rangeland management in south eastern France, with the clear objective of wildfire mitigation (Etienne et al., 1996). Beylier et al. (2006) showed the successful contribution of sheep grazing to fuel control on both a fuel break network and neighbouring areas in the Luberon Natural Park (France). Thavaud (2009) provided practical guidelines for reactivating rangeland management in various ecosystems of the Mediterranean area. They combine new establishments of livestock farmers in fire prone areas, together with consolidation of existing animal farming.

In areas where there are no possibilities of promoting agricultural or pastoral activities, one other alternative to manage shrublands is to carry out afforestations with less fire prone tree species. In terms of forest planning, preference should be given to deciduous broadleaved and mixed forests, usually less fire prone than pine stands or plantations of exotic species. Afforestation policies promoting large scale monocultural stands in former agricultural areas is highly detrimental in terms of fire hazard at the landscape level. Thus, priority should be given to the creation of mosaics of smaller (less than 30 ha) non-contiguous forest patches.

\subsection{Being prepared for large fires and aim at reducing damage rather than reducing area burned}

Large fires are becoming more frequent, at least in some regions. Available evidence indicates that we do not have the technical capabilities to avoid large fires and that they will spread irrespective of LULC planning under extreme fire weather. Even if we tried to increase our technical suppression capacity more, we would simply increase the level at which fuel accumulation creates fire danger conditions that surpass the new suppression capacity. The implication of this is that under certain climatic and fuel load conditions, wildfires will always occur. Strange as it may be to policy makers, fire suppression policies can lead to fuel accumulation and large fire outbreaks. Thus, current fire policies in Mediterranean countries, directed towards reducing the number of ignitions, or having effective fire fighting abilities, will not decrease the number of large wildfires. Stakeholders and managers have to realise that fire-fighters can extinguish most of the fires, but when there is one beyond the extinction capacity, or when the firefighting system collapses because of the large number of concurrent ignitions, a large area will be burned because of the high fuel load resulting from successful fire suppression in previous years. Currently, the unbalanced fire management in Europe, with too much resources being allocated to pre-suppression and suppression actions compared to poor fuel management measures (e.g. Fernandes, 2008), is increasingly questioned. A major shift in the way fire management is seen requires a cross-sectoral approach integrating agricultural, forest and urban policies. Simultaneously, the "learning to live with fire" objective is increasingly shared (Birot and Rigolot, 2009), recognising that fire cannot be excluded from the Mediterranean environment (Rego et al., 2010a). Under this objective, fuel management is not only devoted to limiting wildfire spread, but also to lowering fire impacts on human resources and assets. This new forest management and planning vision also supposes increasing preparedness and response capacity to fire events, especially at the wildland-urban interface (Lampin-Maillet et al., 2010). In the latter, forest and urban planning should be tuned together and citizens living in fire risk areas should also become part of the solution, by building and preparing their homes for the arrival of fire, as well as being well-informed for fire-response planning (defence and evacuation). The contrasting damages caused by two neighbouring simultaneous fires in poorly versus well planned wildland-urban interface settlements near Athens are the best possible argument for planners and convincing proof for people (Xanthopoulos, 2008b).

The success of policies and management has to be evaluated firstly by the amount of damage caused, rather than by the number of hectares burned. Reducing fire damage will be attained by reducing fuel loads and the vulnerability of the values at risk. This means better planning of locations of houses and villages, promoting policies to avoid the increase of the rural-wildland interface, greater awareness of citizens, and the enforcement of existing laws and regulations on fuel management around buildings and villages (Silva et al., 2010).

\subsection{Increase landscape heterogeneity and decrease the probability of repeated burning}

The fact that Mediterranean fire-prone landscapes are increasingly covered by homogeneous shrublands that promote further wildfires creates a dangerous feedback mechanism that has to be stopped. In general, fire propagation may be favoured in landscapes that are homogeneous and hindered at places of greater heterogeneity, and where discontinuities occur. This knowledge can be used in landscape planning, by promoting a diversity of LULC. At the landscape management level, the interspersion of land uses with different fuel loads will counterbalance this trend promoting landscape heterogeneity. In forested regions, this could also be achieved through the spatial planning of stands with different ages to increase fuel load heterogeneity. Furthermore, controlling human behaviour through a better regulation of the use of fire for pastoral burning, particularly by avoiding burning recovering forest patches, could be a first policy measure. In terms of fire prevention in forested areas, top priority should be given to protecting forests that have limited post-fire regeneration ability, namely (a) immature $P$. brutia, $P$. halepensis and $P$. pinaster forests, (b) $P$. nigra and $P$. sylvestris forests, and (c) other forest types with scarce distribution and high conservation value, and for which there is evidence of lack of any active post-fire response mechanisms, such as the Abies forests of Mediterranean mountains (Arianoutsou et al., 2010). Finally, Mediterranean oak forests, that take longer to recover, will not be able to reach maturity unless fire frequency in these ecosystems is highly reduced.

\subsection{Combine landscape compartmentalization with self-protection options}

Under moderate to severe fire weather conditions, fuel management should be focused on increasing the fire suppression options and effectiveness by limiting fire ignition and fire spread in strategic locations. This is what we call compartmentalization, the division of the landscape into blocks that should set a maximum fire size. However, under exceptional weather conditions, the differences of combustibility among land covers will decrease, and fire may propagate throughout a whole landscape regardless of land cover and fuel management. Increasing indirect fire-fighting capability through improved use of backfire and burn-out operations may help achieve better results in controlling maximum fire 
size taking advantage of compartmentalization (Miralles et al., 2010). However, that can never be assured. Thus, under extreme fire weather conditions, prevention strategy should move to selfprotection options by limiting fire intensity and damages on both ecosystems and human assets, and assuming that fire fighting will not always be possible under these circumstances.

The implementation of a fuel break network requires a fire management plan at the landscape level. Landscape fragmentation is ensured by primary and secondary fuel break networks, the former being strategically located (e.g. ridge top fuel breaks) for increasing the efficiency of fire suppression actions, and the latter for guaranteeing the safe accessibility to the former. Following European standards, strategic fuel break width should be not less than 100 m (RCC, 2002; Portuguese Republic, 2009, for France and Portugal respectively).

Both in fuel breaks and area-wide treatments, there is a wide range of possibilities to maintain or promote lower fuel loads, including silvicultural techniques, agricultural and grazing management, or even the use of fire. These treatments will increase the opportunities for safe and successful fire suppression options and reduce the fire severity on the ecosystem or valuable assets (e.g. Rigolot et al., 2009). Several surface fuel management techniques are available including mechanical clearing (increasing fuel compactness), phytocides (limiting plant growth), prescribed burning and controlled grazing (reducing fuel load) (Etienne et al., 1994; Valette et al., 1993; Xanthopoulos et al., 2006). Trees have a role to play for reducing inside stand wind speed and for limiting under storey vegetation growth, and should be maintained, ensuring the appropriate disruption in the vertical and horizontal fuel continuity. Agricultural cultivations and other land uses can be included in fuel break networks as far as they provide a low flammability cover type during the fire season.

The spatial distribution of fuel treatments should better follow a strategic than a random pattern (Fernandes, 2010; Loureiro et al., 2006), and modelling approaches that have been used for optimizing prescribed burning planning can be used at the landscape scale (e.g. Loureiro et al., 2002).

\section{Knowledge gaps}

Several controversial and relevant research topics in the fire-landscape relationships are still not known or totally clarified. We came across the following ones, while carrying out this review:

\subsection{The role of humans in fire danger}

On one hand, land abandonment increases fire hazard, due to fuel accumulation. But at the same time, given that humans account for most of the fire ignitions in the Mediterranean region (see for example Catry et al., 2009; Moreno et al., 1998), it could be hypothesised that a decline in population, and particularly farming activities, would reduce the number of fire ignitions. For instance, Koutsias et al. (2010) claim that demographic shifts from rural to urban areas may favour fuel conditions that lead to large fires, once a fire has been ignited. However, the same population reduction also reduces the probability of (human-caused) fire ignition, simply because less people are around to trigger a fire for whatever reason. Moreover, there is some anecdotal evidence that certain LULC types with low fire hazard can turned into very hazardous ones under improper management. For example, permanent crops such as olive groves and vineyards, which will act as fuel breaks under correct maintenance (periodical removal of grasses and weeds), can facilitate fire spread when not properly managed. On the other end, the increase in the extent of the wildland-urban interface might increase fire danger in areas surrounding villages and settlements. These topics should be clarified.

\subsection{Will climate change increase fire intensity?}

Climate change predictions point out an increase in fire risk, fire intensity, the length of fire seasons, the number of days in each season with extreme fire danger, and area burned per year (e.g. Moriondo et al., 2006; Pausas, 2004). But the detrimental effects of climate change on increased fire occurrence are not always obvious. In the Eastern Iberian Peninsula, Pausas (2004) found a positive correlation between summer rainfall and area burned two years later, suggesting that this rainfall increases fuel loads for the subsequent fire seasons. In this perspective, climate change could decrease fire hazard by constraining vegetation growth and biomass (fuel accumulation). This author concluded that more research is needed on the potential impact of lower but drier fuel loads on future fire regimes.

\subsection{Is fire size limited by weather or landscape pattern?}

There is still a debate on whether landscape pattern or meteorological conditions is the fundamental control of fire spread in Mediterranean landscapes. A better understanding of these processes has strong implications for landscape planning, and to the expected role LULC management has in reducing fire extent of fire damages.

\subsection{Does fire suppression policies increase large fire occurrence?}

Further research is needed on the impact of fire suppression policies on resulting fire sizes. If scientific research shows beyond doubt that fire suppression policies, if not accompanied by fuel management, lead to fuel accumulation and are responsible for large fire outbreaks, a major shift on resource allocation from suppression to prevention should be made.

\subsection{The role of invasive exotic species in fire hazard}

Scientific evidence also suggests that controlling the spread of invasive species in burned areas could decrease future fire hazard. Exotic invasive species are becoming a major problem in Europe (Lambdon et al., 2008) and in specific regions (e.g. Portugal) they are one of the main concerns of forest managers in burned areas. Their role on fire regime and post-fire ecosystem responses need to be further evaluated.

\section{Acknowledgements}

This study was carried out under the scope of COST Action FP0701 "Post-fire forest management in southern Europe" and the PHOENIX network of the European Forest Institute. Support from projects IFAP-IP “Recuperação de áreas ardidas”, FIRELAND (FCT Project PTDC/AGR-CFL/104651/2008) and FIREREG (FCT Project PTDC/AGR-CFL/099420/2008) is also acknowledged.

\section{References}

Acácio, V., Holmgren, M., Rego, F., Moreira, F., Mohren, G.M.J., 2009. Are drought and wildfires turning Mediterranean cork oak forests into persistent shrublands? Agroforestry Systems 76, 389-400.

Acosta, A., Carranza, M.L., Giancola, M., 2005. Landscape change and ecosystem classification in a municipal district of a small city (Isernia, central Italy). Environmental Monitoring and Assessment 108, 323-335.

Agee, J.K., Bahro, B., Finney, M., Omi, P., Sapsis, D.B., Skinner, C.N., van Wagtendonk, J.W., Weatherspoon, C.P., 2000. The use of shaded fuelbreaks in landscape fire management. Forest Ecology and Management 127, 55-66. 
Alphan, H., Yilmaz, K.T., 2005. Monitoring environmental changes in the Mediterranean coastal landscape: the case of Cukurova, Turkey. Environmenta Management 35, 607-619.

Alvarez, R., Munoz, A., Pesqueira, X.M., Garcia-Duro, J., Reyes, O., Casal, M., 2009 Spatial and temporal patterns in structure and diversity of Mediterranean forest of Quercus pyrenaica in relation to fire. Forest Ecology and Management 257, 1596-1602.

Amouric, H., 1992. Le feu à l'épreuve du temps. Narration, Aix-en-Provence.

Aranzabal, I., Schmitz, M.F., Aguilera, P., Pineda, F.D., 2008. Modelling of landscape changes derived from the dynamics of socio-ecological systems: a case of study in a semiarid Mediterranean landscape. Ecological Indicators 8, 672-685.

Arca, B., Duce, P., Laconi, M., Pellizzaro, G., Salis, M., Spano, D., 2007. Evaluation of FARSITE simulator in Mediterranean maquis. International Journal of Wildland Fire $16,563-572$

Arianoutsou, M., 1985. Desertification by overgrazing in Greece: the case of Lesvos island. Journal of Arid Environments 9, 237-242.

Arianoutsou, M., 1998. Aspects of demography in post-fire Mediterranean plant communities of Greece. In: Rundel, P.W., Montenegro, G., Jaksic, F. (Eds.) Landscape Disturbance and Biodiversity in Mediterranean-Type Ecosystems. Ecological Studies, vol. 136. Springer - Verlag, Berlin, pp. 273-295.

Arianoutsou, M., 2001. Landscape changes in Mediterranean ecosystems of Greece: implications for fire and biodiversity issues. Journal of Mediterranean Ecology 2, 165-178.

Arianoutsou, M., 2007. Resilience of Mediterranean vegetation to fire: issues under the global change scenarios. In: Rokich, D., Wardell-Johnson, G., Yates, C., Stevens, J., Dixon, K., R. McLellan, R., Moss, G. (Eds.), Proceedings of the MEDECOS XI 2007 Conference, Perth, Australia. Kings Park and Botanic Garden, Perth, Australia, pp. 5-7.

Arianoutsou, M., Kazanis, D., Kokkoris, Y., Skourou, P., 2002. Land-use interactions with fire in Mediterranean Pinus halepensis landscapes of Greece: patterns of biodiversity. In: Viegas, D.X. (Ed.), Forest Fire Research and Wildland Fire Safety, Proceedings of the IV International Conference on Forest Fire Research/2002 Wildland Fire Safety Summit. University of Coimbra, Coimbra, Portugal. Millpress, Rotterdam CD-ROM.

Arianoutsou, M., Christopoulou, A., Tountas, Th., Ganou, E., Kazanis, D., Bazos, I. Kokkoris, Y. , 2010. Effects of fire on high altitude coniferous forests of Greece. In: Viegas D.X. (Ed.), VI International Forest Fire Research Conference, Coimbra, Portugal, electronic edition.

Badia-Perpinya, A., Pallares-Barbera, M., 2006. Spatial distribution of ignitions in Mediterranean periurban and rural areas: the case of Catalonia. International Journal of Wildland Fire 15, 187-196.

Baeza, M.J., Vallejo, V.R., 2008. Vegetation recovery after fuel management in Mediterranean shrublands. Applied Vegetation Science 11, 151-158.

Baeza, M., Valdecantos, A., Alloza, J., Vallejo, V., 2007. Human disturbance and environmental factors as drivers of long-term post-fire regeneration patterns in Mediterranean forests. Journal of Vegetation Science 18, 243-252.

Bajocco, S., Ricotta, C., 2008. Evidence of selective burning in Sardinia (Italy): which land-cover classes do wildfires prefer? Landscape Ecology 23, 241-248.

Baudry, J., Tatoni, T., 1993. Changes in landscape patterns and vegetation dynamics in Provence, France. Landscape and Urban Planning 24, 153-159.

Bermudez, Z., Mendes, J., Pereira, J.M.C., Turkman, K.F., Vasconcelos, M.J.P., 2009. Spatial and temporal extremes of wildfire sizes in Portugal. International Journal of Wildland Fire 18, 983-991.

Beylier, B., Kmiec, L., Etienne, M., 2006. Une coupure de combustible en Luberon bilan de douze ans de suivis pastoralistes, DFCI et environnementaux. In Réseau Coupures de combustible, vol. 10. Editions de la Cardère, Morières.

Bilgili, E., 1998. Forest fires and fire management policies in Turkey. In: Proceedings FAO Meeting on Public Policies Affecting Forest Fires, FAO Forestry Paper No: 138, pp. 357-362.

Birot, Y., Rigolot, E., 2009. The need for strategy anticipating climate ... and other changes. In: Birot, Y. (Ed.), Living with Wildfire: What Science Can Tell Us. EFI Discussion Paper, vol. 15. EFI, Joensuu, pp. 75-78.

Blasi, C., Bovio, G., Corona, P., Marchetti, M., Maturani, A. (Eds.), 2004. Fires and Ecosystem Complexity. From Forest Assessment to Habitat Restoration. Executive summary. Ministero dell'Ambiente e della Tutela del Territorio, Società Botanica Italiana, Palombi \& Partner, Roma, Italy.

Boboulos, M., Purvis, M.R.I., 2009. Wind and slope effects on ROS during the fire propagation in east-Mediterranean pine forest litter. Fire Safety Journal 44 764-769.

Broncano, M.J., Retana, J., 2004. Topography and forest composition affecting the variability in fire severity and post-fire regeneration occurring after a large fire in the Mediterranean basin. International Journal of Wildland Fire 13 209-216.

Buhk, C., Meyn, A., Jentsch, A., 2007. The challenge of plant regeneration after fire in the Mediterranean basin: scientific gaps in our knowledge on plant strategies and evolution of traits. Plant Ecology 192, 1-19.

Calvo, L., Tarrega, R., De Luis, E., 2002a. Secondary succession after perturbations in a shrubland community. Acta Oecologica-International Journal of Ecology 23 393-404.

Calvo, L., Tarrega, R., De Luis, E., 2002b. The dynamics of mediterranean shrubs species over 12 years following perturbations. Plant Ecology 160, 25-42.

Camia, A., San-Miguel-Ayanz, J., Kucera, J., Amatulli, G., Boca, R., Libertà, G. Durrant, T., Schmuck, G., Schulte, E., Bucki, M., 2008. Forest Fires in Europe 2007. Joint Research Centre - Institute for Environment and Sustainability, Office for Official Publications of the European Communities, Luxembourg.
Carmel, Y., Flather, C.H., 2004. Comparing landscape scale vegetation dynamics following recent disturbance in climatically similar sites in California and the Mediterranean basin. Landscape Ecology 19, 573-590.

Carmel, Y., Kadmon, R., 1999. Effects of grazing and topography on long-term vegetation changes in a Mediterranean ecosystem in Israel. Plant Ecology 145, 243-254.

Carmel, Y., Paz, S., Jahashan, F., Shoshany, M., 2009. Assessing fire risk using Monte Carlo simulations of fire spread. Forest Ecology and Management 257, 370-377.

Carmo, M., Moreira, F., Casimiro, P., Vaz, P., 2011. Land use and topography influences on wildfire occurrence in northern Portugal. Landscape and Urban Planning 100, 169-176.

Carracedo, V., Diego Liaño, C., García Codrón, J.C., Rasilla Álvarez, D.F., 2006. An advance of the role of human and natural factors in the genesis of forest fires in Cantabria (Northern Spain). Forest Ecology and Management 234 (Suppl. 1), S16.

Catry, F.X., Rego, F.C., Bação, F., Moreira, F., 2009. Modelling and mapping wildfire ignition risk in Portugal. International Journal of Wildland Fire 18, 921-931.

CFS, 2005, 2006, 2007, 2008, 2009. Rapporto annuale incendi boschivi. Corpo Forestale dello Stato, Roma, Italy.

Chandler, C., Cheney, P., Thomas, P., Trabaud, L., Williams, D., 1983. Fire in Forestry, Vol. II: Forest Fire Management and Organization. John Wiley \& Sons, NewYork.

Chuvieco, E., 1999. Measuring changes in landscape pattern from satellite images: short-term effects of fire on spatial diversity. International Journal of Remote Sensing 20, 2331-2346.

Collins, B.M., Kelly, M., van Wagtendonk, J.W., Stephens, S.L., 2007. Spatial patterns of large natural fires in Sierra Nevada wilderness areas. Landscape Ecology 22, 545-557.

Corona, P., Fattorini, L., Pompei, E., 2007. Aerial assessment of landscape net change by means of two-phase network sampling: an application to central Italy. Environmetrics 18, 205-215.

Cumming, S.G., 2001. Forest type and wildfire in the Alberta boreal mixedwood: what do fires burn? Ecological Applications 11, 97-110.

Curt, T., Delcros, P., 2010. Managing road corridors to limit fire hazard. A simulation approach in southern France. Ecological Engineering 4, 1-12.

Davidson, S., 1988. Predicting the effectiveness of firebreaks. Rural Research 139, $11-16$

Davis, L.S., 1965. The Economics of Wildfire Protection with Emphasis on Fuel Break Systems. California Division of Forestry, Sacramento, CA

De la Cueva, A.V., del Barrio, J.M.G., Quero, M.O., Palomares, O.S., 2006. Recent fire regime in peninsular Spain in relation to forest potential productivity and population density. International Journal of Wildland Fire 15, 397-405.

Debussche, M., Lepart, J., Dervieux, A., 1999. Mediterranean landscape changes: evidence from old postcards. Global Ecology and Biogeography 8, 3-15.

Debussche, M., Debussche, G., Lepart, J., 2001. Changes in the vegetation of Quercus pubescens woodland after cessation of coppicing and grazing. Journal of Vegetation Science 12, 81-92.

Diaz-Delgado, R., Pons, X., 2001. Spatial patterns of forest fires in Catalonia (NE of Spain) along the period 1975-1995. Analysis of vegetation recovery after fire. Forest Ecology and Management 147, 67-74.

Diaz-Delgado, R., Lloret, F., Pons, X., Terradas, J., 2002. Satellite evidence of decreasing resilience in Mediterranean plant communities after recurrent wildfires. Ecology 83, 2293-2303.

Diaz-Delgado, R., Lloret, F., Pons, X., 2004. Spatial patterns of fire occurrence in Catalonia, NE, Spain. Landscape Ecology, 731-745.

Duché, Y., Rigolot, E., 2000. Mises au point préliminaires. In: Rigolot, E., Costa, M. (Eds.), Conception des Coupures de combustible. RCC, vol. 4. Edition de la Cardère Morières, pp. 17-19.

Duguy, B., Alloza, J.A., Roder, A., Vallejo, R., Pastor, F., 2007. Modelling the effects of landscape fuel treatments on fire growth and behaviour in a Mediterranean landscape (eastern Spain). International Journal of Wildland Fire 16, 619-632.

Dupuy, J.L., 2009. Fire start and spread. In: Birot, Y. (Ed.), Living with Wildfire: What Science Can Tell Us. EFI Discussion Paper, vol. 15. EFI, Joensuu, pp. 27-31.

Espelta, J.M., Retana, J., Habrouk, A., 2003. Resprouting patterns after fire and response to stool cleaning of two coexisting Mediterranean oaks with contrasting leaf habits on two different sites. Forest Ecology and Management 179, 401-414.

Espelta, J.M., Verkaik, I., Eugenio, M., Lloret, F., 2008. Recurrent wildfires constrain long-term reproduction ability in Pinus halepensis Mill. International Journal of Wildland Fire 17, 579-585.

Etienne, M. Mas, I., Rigolot, E, 1994. Combining techniques of fuel reduction for fuel-break maintenance in the French Mediterranean region. In: Viegas, D.X (Ed.), Proceedings 2nd International Conference on Forest Fire Research, vol. II. Universidade de Coimbra, pp. 713-721.

Etienne, M., Dzerko, M., Rigolot, E., 1996. Browse impact in silvopastoral systems participating in fire prevention in the French Mediterranean region. In: Etienne, M. (Ed.), Western European Silvopastoral Systems. INRA Editions, Paris, pp. 93-102.

Eugenio, M., Lloret, F., 2004. Fire recurrence effects on the structure and composition of Mediterranean Pinus halepensis communities in Catalonia (northeast Iberian Peninsula). Ecoscience 11, 446-454.

Eugenio, M., Verkaik, I., Lloret, F., Espelta, J.M., 2006. Recruitment and growth decline in Pinus halepensis populations after recurrent wildfires in Catalonia (NE Iberian Peninsula). Forest Ecology and Management 231, 47-54.

Falcucci, A., Maiorano, L., Boitani, L., 2007. Changes in land-use/land-cover patterns in Italy and their implications for biodiversity conservation. Landscape Ecology 22, 617-631 
Fernandes, P., 2008. Forest fires in Galicia (Spain): the outcome of unbalanced fire management. Letter to the editor. Journal of Forest Economics 14, 155-157.

Fernandes, P., 2009. Combining forest structure data and fuel modelling to classify fire hazard in Portugal. Annals of Forest Science 66.

Fernandes, P., 2010. Scientific knowledge and operational tools to support prescribed burning: recent developments. In: Silva, J.S., Rego, F., Fernandes, P., Rigolot, E. (Eds.), Towards Integrated Fire Management - Outcomes of the European Project Fire Paradox. European Forest Institute Research Report, vol. 23, pp. $151-159$

Fernandes, P., Botelho, H., 2003. A review of prescribed burning effectiveness in fire hazard reduction. International Journal of Wildland Fire 12, 117-128.

Fernandes, P.M., Luz, A., Loureiro, C., 2010. Changes in wildfire severity from maritime pine woodland to contiguous forest types in the mountains of northwestern Portugal. Forest Ecology and Management 260, 883-892.

Finney, M.A., 1998. FARSITE: Fire Area Simulator-model Development and Evaluation. Res. Pap. RMRS-RP-4. Department of Agriculture, Rocky Mountain Research Station, OGDEN, UT: U.S, 47 pp.

Fontaine, M., Aerts, R., Ozkan, K., Mert, A., Gulsoy, S., Suel, H., Waelkens, M., Muys, B., 2007. Elevation and exposition rather than soil types determine communities and site suitability in Mediterranean mountain forests of southern Anatolia, Turkey. Forest Ecology and Management 247, 18-25.

Forman, R.T., 1997. Land Mosaics. The Ecology of Landscapes and Regions. Cambridge University Press, Cambridge, UK.

Fule, P.Z., Ribas, M., Guttierez, E., Vallejo, R., Kaye, M.W., 2008. Forest structure and fire history in an old Pinus Nigra forest, eastern Spain. Forest Ecology and Management 255, 1234-1242.

Garcia-Fayos, P., Racatala, T.M., Cerda, A., Calvo, A., 1995. Seed population dynamics on badlands slopes in southeastern Spain. Journal of Vegetation Science 6, 691-696.

Gill, A.M., Allan, G., 2008. Large fires, fire effects and the fire regime concept International Journal of Wildland Fire 17, 688-695.

Gomes, J.F.P., Radovanovic, M., 2008. Solar activity as a possible cause of large forest fires - a case study: analysis of the Portuguese forest fires. Science of the Total Environment 394, 197-205.

Gonzalez, J.R., Pukkala, T., 2007. Characterization of forest fires in Catalonia (northeast Spain). European Journal of Forest Research 126, 421-429.

Gonzalez, J.R., Palahi, M., Pukkala, T., 2005. Integrating fire risk considerations in forest management planning in Spain - a landscape level perspective. Landscape Ecology 20, 957-970.

Gonzalez, J.R., Palahi, M., Trasobares, A., Pukkala, T., 2006. A fire probability model for forest stands in Catalonia (north-east Spain). Annals of Forest Science 63 $169-176$.

Gonzalez, J.R., Barrio, G., Duguy, B., 2008. Assessing functional landscape connectivity for disturbance propagation on regional scales - a cost-surface model approach applied to surface fire spread. Ecological Modelling 211, $121-141$.

Good, P., Moriondo, M., Giannakopoulos, C., Bindi, M., 2008. The meteorological conditions associated with extreme fire risk in Italy and Greece: relevance to climate model studies. International Journal of Wildland Fire 17, 155-165.

Gracia, M., Retana, J., Roig, P., 2002. Mid-term successional patterns after fire of mixed pine-oak forests in NE Spain. Acta Oecologica-International Journal of Ecology 23, 405-411.

Grigulis, K., Lavorel, S., Davies, I.D., Dossantos, A., Lloret, F., Vila, M., 2005. Landscape-scale positive feedbacks between fire and expansion of the large tussock grass, Ampelodesmos mauritanica in Catalan shrublands. Global Change Biology $11,1042-1053$.

Hardy, C., 2005. Wildland fire hazard and risk: problems, definitions, and context. Forest Ecology and Management 211, 73-82.

Helms, J.A., 1988. The Dictionary of Forestry. The Society of American Foresters, Bethesda, MD

Hernandez-Clemente, R., Cerrillo, R., Hernandez-Bermejo, J.E., Royo, S.E., Kasimis, N.A., 2009. Analysis of postfire vegetation dynamics of Mediterranean shrub species based on terrestrial and NDVI data. Environmental Management 43, 876-887.

Hill, J., Stellmes, M., Udelhoven, T., Röder, A., Sommer, S., 2008. Mediterranean desertification and land degradation: mapping related land use change syndromes based on satellite observations. Global and Planetary Change 64, 146-157.

JRC, 2005. Forest Fires in Europe 2004 Joint Research Center S.P.l.05.147 EN, European Communities.

Jacquet, K., Prodon, R., 2009. Measuring the postfire resilience of a bird-vegetation system: a 28-year study in a Mediterranean oak woodland. Oecologia 161, 801-811.

Jomaa, I., Auda, Y., Abi Saleh, B., Hamzé, M., Safi, S., 2008. Landscape spatial dynamics over 38 years under natural and anthropogenic pressures in Mount Lebanon. Landscape and Urban Planning 87, 67-75.

Kazanis, D., Arianoutsou, M., 2004. Long-term post-fire vegetation dynamics in Pinus halepensis forests of central Greece: a functional group approach. Plant Ecology 171, 101-121.

Kazanis, D., Gimeno, T., Pausas, J.G., Vallejo, R., Arianoutsou, M., 2007. Characterization of fire vulnerable Pinus halepensis ecosystems in Spain and Greece. Options Mediterranéennes 75, 131-143.

Kazanis, D., Gimeno, T., Pausas, J.G., Vallejo, R., Arianoutsou, M. 2009. Assessing the effect of reduced fire interval on Pinus halepensis Mill communities: a comparative study from Spain and Greece, In: Book of Abstracts of the 52nd
International Symposium of International Association for Vegetation Science, May 30-4th June, Chania, Crete, pp. 73.

Keeley, J.E., 2009. Fire intensity, fire severity and burn severity: a brief review and suggested usage. International Journal of Wildland Fire 18, 116-126.

Keyser, T.L., Smith, F.W., Shepperd, W.D., 2009. Short-term impact of post-fire salvage logging on regeneration, hazardous fuel accumulation and understory development in ponderosa pine forests of the Black Hills, SD, USA. International Journal of Wildland Fire 18, 451-458.

Kilinc, M., Beringer, J., 2007. The spatial and temporal distribution of lightning strikes and their relationship with vegetation type, elevation, and fire sears in the northern territory. Journal of Climate 20, 1161-1173.

Koutsias, N., Karteris, M., 1998. Logistic regression modelling of multitemporal Thematic Mapper data for burned area mapping. International Journal of Remote Sensing 19, 3499-3514.

Koutsias, N., Arianoutsou, M., Kallimanis, A.S., Dimopoulos, P., 2009. Is there any special pattern of the extreme wildland fires occurred in Greece in the summer of 2007? In: 52nd International Symposium of the International Association for Vegetation Science, Vegetation Processes and Human Impact in a Changing World, Chania, Greece.

Koutsias, N., Martínez-Fernández, J., Allgower, B., 2010. Do factors causing wildfires vary in space? Evidence from geographically weighted regression. GIScience and Remote Sensing 47, 221-240.

Lambdon, P.W., Pyšek, P., Basnou, C., Arianoutsou, M., Essl, F., Hejda, M., Jarosik, V. Pergl, J., Winter, M., Anastasiu, P., Andriopoulos, P., Bazos, I., Brundu, G., CelestiGrapow, L., Chassot, P., Delipetrou, P., Jossefson, M., Kark, S., Klotz, S., Kokkoris, Y., Kuhn, I., Marchante, H., Perglova, I., Pino, J., Vilà, M., Zikos, A., Roy, D., Hulme, P.H., 2008. Alien flora of Europe: species diversity, temporal trends, geographical patterns and research. Preslia 80, 101-149.

Lambert, B., Casteignau, D., Costa, M., Etienne, M., Guiton, J.L., Rigolot, E., 1999. Analyse après incendie de six coupures de combustible. In: RCC, vol. 2. Ed. de la Cardère Morières, $81 \mathrm{pp}$.

Lampin-Maillet, C., Mantzavelas, A., Galiana, L., Jappiot, M., Long, M., Herrero, G., Karlsson, O., Iossifina, A., Thalia, L., Thanassis, P., 2010. Wildland urban interface, fire behaviour and vulnerability: characterization, mapping and assessment. In: Silva, J.S., Rego, F., Fernandes, P., Rigolot, E. (Eds.), Towards Integrated Fire Management - Outcomes of the European Project Fire Paradox. European Forest Institute Research Report, vol. 23, pp. 71-92.

Lloret, F., Marí, G., 2001. A comparison of the medieval and the current fire regimes in managed pine forests of Catalonia (NE Spain),. Forest Ecology and Management 141, 155-163.

Lloret, F., Calvo, E., Pons, X., Díaz-Delgado, R., 2002. Wildfires and landscape patterns in the eastern Iberian Peninsula. Landscape Ecology 17, 745-759.

Lloret, F., Pausas, J.G., Vilà, M., 2003. Responses of Mediterranean plant species to different fire frequencies in Garraf Natural Park (Catalonia, Spain): field observations and modelling. Plant Ecology, 223-235.

Loepfe, L., Martinez-Vilalta, J., Oliveres, J., Piñol, J., Lloret, F., 2010. Feedbacks between fuel reduction and landscape homogenisation determine fire regimes in three Mediterranean areas. Forest Ecology and Management 259, 2366-2374.

Loureiro, C., Fernandes, P., Botelho, H., 2002. Optimizing prescribed burning to reduce wildfire propagation at the landscape scale. In: Viegas, D.X. (Ed.), Forest Fire Research and Wildland Fire Safety, Proceedings of the IV Internationa Conference on Forest Fire Research/2002 Wildland Fire Safety Summit. University of Coimbra, Coimbra, Portugal. Millpress, Rotterdam, CD-ROM. 9 pp.

Loureiro, C., Fernandes, P., Botelho, H., Mateus, P., 2006. A simulation-based test of a landscape fuel management project in the Marão range of northern Portugal. In: Viegas, D.X. (Ed.), Proceedings of the 5th International Conference on Forest Fire Research. Elsevier B.V., Amsterdam CD-ROM.

Lyrintzis, G.A., 1996. Human impact trend in Crete: the case of Psilorites Mountain. Environmental Conservation 23, 140-148.

MacDonald, D., Crabtree, J.R., Wiesinger, G., Dax, T., Stamou, N., Fleury, P., Lazpita, J.G., Gibon, A., 2000. Agricultural abandonment in mountain areas of Europe: environmental consequences and policy response. Journal of Environmental Management 59, 47-69.

Martinez, J., Vega-Garcia, C., Chuvieco, E., 2009. Human-caused wildfire risk rating for prevention planning in Spain. Journal of Environmental Management 90, 1241-1252.

Mazzoleni, S., Pasquale, G., Mullingan, M., Martino, P., Rego, F., 2004. Recent Dynamics of the Mediterranean Vegetation and Landscape. John Wiley \& Sons, Chichester.

Mermoz, M., Kitzberger, T., Veblen, T.T., 2005. Landscape influences on occurrence and spread of wildfires in Patagonian forests and shrublands. Ecology 86, 2705-2715.

Miralles, M., Kraus, D., Molina, D., Loureiro, C., Delogu, G., Ribet, N., Vivalta, O., 2010. Improving suppression fire capacity. In: Silva, et al. (Eds.), Towards Integrated Fire Management - Outcomes of the European Project Fire Paradox. European Forest Institute Research Report, vol. 23, pp. 203-214.

Moreira, F., Russo, D., 2007. Modelling the impact of agricultural abandonment and wildfires on vertebrate diversity in Mediterranean Europe. Landscape Ecology 22, 1461-1476.

Moreira, F., Rego, F.C., Ferreira, P.G., 2001. Temporal (1958-1995) pattern of change in a cultural landscape of northwestern Portugal: implications for fire occurrence. Landscape Ecology 16, 557-567.

Moreira, F., Vaz, P., Catry, F., Silva, J.S., 2009. Regional variations in wildfire susceptibility of land-cover types in Portugal: implications for landscape 
management to minimize fire hazard. International Journal of Wildland Fire 18, 563-574.

Moreno, J.M., Vazquez, A., Velez, R., 1998. Recent history of forest fires in Spain. In: Moreno, J.M. (Ed.), Large Forest Fires. Backhuys Publishers, Leiden, The Netherlands, pp. 159-185.

Moreno, J.M., Viedma, O., Zavala, G., Luna, B. Forest fires in central Spain burn selectively the landscape. International Journal of Wildland Fire, in press.

Moriondo, M., Good, P., Durao, R., Bindi, M., Giannakopoulos, C., CorteReal, J., 2006 Potential impact of climate change on fire risk in the Mediterranean area. Climate Research 31, 85-95.

Moritz, M.A., Moody, T.J., Krawchuk, M.A., Hughes, M., Hall, A., 2010. Spatial variation in extreme winds predicts large wildfire locations in chaparral ecosystems. Geophysical Research Letters 37, L04801.

Mouillot, F., Rambal, S., Joffre, R., 2002. Simulating climate change impacts on fire frequency and vegetation dynamics in a Mediterranean-type ecosystem. Global Change Biology, 423-437.

Mouillot, F., Ratte, J.P., Joffre, R., Moreno, J.M., Rambal, S., 2003. Some determinants of the spatio-temporal fire cycle in a Mediterranean landscape (Corsica, France). Landscape Ecology 18, 665-674.

Mouillot, F., Ratte, J., Joffre, R., Mouillot, D., Rambal, S., 2005. Long-term forest dynamic after land abandonment in a fire prone Mediterranean landscape (central Corsica, France). Landscape Ecology 20, 101-112.

Nunes, M.C.S., Vasconcelos, M.J., Pereira, J.M.C., Dasgupta, N., Alldredge, R.J., 2005. Land cover type and fire in Portugal: do fires burn land cover selectively? Landscape Ecology 20, 661-673.

Olarieta, J., Rodríguez-Valle, F., Tello, E., 2008. Preserving and destroying soils, transforming landscapes: soils and land-use changes in the Vallès County (Catalunya, Spain) 1853-2004. Land Use Policy 25, 474-484.

Oliveras, I., Piñol J., 2006. Relationships among number of fires, total area burnt, and large fires in southern France, eastern Spain and Portugal. In: First International Symposium on Environment Identities and Mediterranean Area, vol. 1, IEEE New York, pp. 107-110. 345 E 47th St, New York, NY 10017 USA.

Oliveras, I., Gracia, M., Moré, G., Retana, J., 2009. Factors influencing the pattern of fire severities in a large wildfire under extreme meteorological conditions in the Mediterranean basin. International Journal of Wildland Fire 18, 755-764.

Pérez, B., Cruz, A., Fernández-González, F., Moreno, J.M., 2003. Effects of the recent land-use history on the postfire vegetation of uplands in central Spain. Forest Ecology and Management 182, 273-283.

Pérez, B., Moreno, J.M., 1998. Methods for quantifying fire severity in shrublandfires. Plant Ecology 139, 91-101.

Papanastasis, V.P., Ispikoudis, I., Arianoutsou, M., Kakouros, P., Kazaklis, A., 2004 Landuse changes and landscape dynamics in Western Crete. In: Mazzoleni, S., Pasquale, G., Mullingan, M., Martino, P., Rego, F. (Eds.), Recent Dynamics of the Mediterranean Vegetation and Landscape. John Wiley \& Sons, Chichester, pp. 81-95.

Pausas, J.G., 1999. Response of plant functional types to changes in the fire regime in Mediterranean ecosystems: a simulation approach. Journal of Vegetation Science 10, 717-722.

Pausas, J.G., 2004. Changes in fire and climate in the eastern Iberian Peninsula (Mediterranean basin). Climatic Change 63, 337-350.

Pausas, J.G., Fernandez-Muñoz, S. Fire regime changes in the western Mediterranean basin: from fuel-limited to drought-driven fire regime. Climatic change, in press.

Pausas, J.G., Lloret, F., 2007. Spatial and temporal patterns of plant functional types under simulated fire regimes. International Journal of Wildland Fire 16 484-492.

Pausas, J.G., Blade, C., Valdecantos, A., Seva, J.P., Fuentes, D., Alloza, J.A., Vilagrosa, A., Bautista, S., Cortina, J., Vallejo, R., 2004a. Pines and oaks in the restoration of Mediterranean landscapes of Spain: new perspectives for an old practice a review. Plant Ecology 171, 209-220.

Pausas, J.G., Llovet, J., Rodrigo, A., Vallejo, R., 2008. Are wildfires a disaster in the Mediterranean basin? - a review. International Journal of Wildland Fire 17, 713-723.

Peñuelas, J., Ogaya, R., Boada, M., Jump, A.S., 2007. Migration, invasion and decline: changes in recruitment and forest structure in a warming-linked shift of European beech forest in Catalonia (NE Spain). Ecography 30, 829-837.

Perchat, S., Rigolot, E. (Eds.), 2005. Comportement au feu et utilisation par les forces de lutte des coupures de combustible touches par les grands incendies de la saison 2003 Réseau Coupures de combustible - Ed. de la Cardère Morières.

Pereira, M.G., Trigo, R.M., Da Camara, C.C., Pereira, J.M.C., Leite, S.M., 2005. Synoptic patterns associated with large summer forest fires in Portugal. Agricultural and Forest Meteorology 129, 11-25.

Peroni, P., Ferri, F., Avena, G.C., 2000. Temporal and spatial changes in a mountainous area of central Italy. Journal of Vegetation Science 11, 505-514.

Piñol, J., Terradas, J., Lloret, F., 1998. Climate warming and wildfire hazard and wildfire occurrence in coastal eastern Spain. Climatic Change 38, 345-357.

Piñol, J., Beven, K., Viegas, D., 2005. Modelling the effect of fire-exclusion and prescribed fire on wildfire size in Mediterranean ecosystems. Ecological Modelling 183, 397-409.

Pimont, F., Linn, R.R., Dupuy, J.L., Morvan, D., 2006. Effects of vegetation description parameters on forest fire behavior with FIRETEC. Forest Ecology and Management 234 (Suppl. 1), S120.

Pimont, F., Dupuy, J.L., Linn, R.R., Dupont, S., 2009. Validation of FIRETEC wind-flows over a canopy and a fuel-break. International Journal of Wildland Fire 18, $775-790$.
Podur, J.J., Martell, D.L., 2009. The influence of weather and fuel type on the fuel composition of the area burned by forest fires in Ontario, 1996-2006. Ecological Applications 19, 1246-1252.

Portuguese Republic. 2009. Diário da República, 1a série - N. 9-14 de Janeiro de 2009, Artigo vol. 18. p. 289.

Preiss, E., Martin, J., Debussche, M., 1997. Rural depopulation and recent landscape changes in a Mediterranean region: consequences to the breeding avifauna. Landscape Ecology 12, 51-61.

Price, C., Rind, D., 1994. The impact of a 2-X-Co2 climate on lightning-caused fires. Journal of Climate 7, 1484-1494.

RCC, 2002. Du plan départemental à la coupure de combustible: guide méthodologique et pratique. In: Réseau Coupures de combustible, vol. 6. Editions de la Cardère, Morières, 48 pp.

Rana, G., Katerji, N., de Lorenzi, F., 2005. Measurement and modelling of evapotranspiration of irrigated citrus orchard under Mediterranean conditions. Agricultural and Forest Meteorology 128, 199-209.

Rego, F.C., 1992. Land use changes and wildfires. In: Teller, A., Mathy, P., Jeffers, J.N.R. (Eds.), Response of Forest Fires to Environmental Change. Elsevier, London, pp. 367-373.

Rego, F., Rigolot, E., Fernandes, P., Montiel, C., Silva, J.S., 2010a. Towards Integrated Fire Management. In: European Forest Institute Policy Brief, vol. 4, 14 pp.

Rego, F., Silva, J.S., Fernandes, P., Rigolot, E., 2010b. Solving the Fire Paradox regulating the wildfire problem by the wise use of fire. In: Silva, J.S., Rego, F. Fernandes, P., Rigolot, E. (Eds.), Towards Integrated Fire Management Outcomes of the European Project Fire Paradox. European Forest Institute Research Report, vol. 23, pp. 220-228.

Rescia, A.J., Schmitz, M.F., Deagar, P.M., Depablo, C.L., Atauri, J.A., Pineda, F.D., 1994 Influence of landscape complexity and land management on woody plant diversity in northern Spain. Journal of Vegetation Science 5, 505-516.

Retana, J., Espelta, J.M., Habrouk, A., Ordonez, J.L., Sola-Morales, F., 2002. Regeneration patterns of three Mediterranean pines and forest changes after a large wildfire in northeastern Spain. Ecoscience 9, 89-97.

Rigolot, E., 2002. Fuel-break assessment with an expert appraisement approach. In: Viegas, D.X. (Ed.), Forest Fire Research and Wildland Fire Safety, Proceedings of the IV International Conference on Forest Fire Research/2002 Wildland Fire Safety Summit. University of Coimbra, Coimbra, Portugal. Millpress, Rotterdam CD-ROM.

Rigolot, E., Alexandrian, D., 2006. Learning from fuel-break behaviour during the 2003 large fires in south eastern France. Forest Ecology and Management, 234S.

Rigolot, E., Morvan, D., 2003. Evaluation de l'efficacité des coupures de combustible par deux approches: dires d'experts et modélisation. Forêt Méditerranéenne 24, 403-418.

Rigolot, E., Fernandes, P., Rego, F., 2009. Managing wildfire risk: prevention, suppression. In: Birot, Y. (Ed.), Living with Wildfire: What Science Can Tell Us. EFI Discussion Paper, vol. 5. EFI, Joensuu, pp. 50-52.

Roder, A., Hill, J., Duguy, B., Alloza, J.A., Vallejo, R., 2008. Using long time series of Landsat data to monitor fire events and post-fire dynamics and identify driving factors. A case study in the Ayora region (eastern Spain). Remote Sensing of Environment 112, 259-273.

Rodrigo, A., Retana, J., Pico, F.X., 2004. Direct regeneration is not the only response of Mediterranean forests to large fires. Ecology 85, 716-729.

Rodrigo, A., Quintana, V., Retana, J., 2007. Fire reduces Pinus pinea distribution in the northeastern Iberian Peninsula. Ecoscience 14, 23-30.

Romero-Calcerrada, R., Perry, G.L.W., 2004. The role of land abandonment in landscape dynamics in the SPA 'Encinares del rio Alberche y Cofio, Central Spain, 1984-1999. Landscape and Urban Planning 66, 217-232.

Romero-Calcerrada, R., Barrio-Parra, F., Millington, J.D.A., Novillo, C.J., 2010. Spatial modelling of socioeconomic data to understand patterns of human-caused wildfire ignition risk in the SW of Madrid (central Spain). Ecological Modelling 221, 34-45.

Romme, W.H., Everham, E.H., Frelich, L.E., Moritz, M.A., Sparks, R.E., 1998. Are large, infrequent disturbances qualitatively different from small, frequent disturbances? Ecosystems 1, 524-534.

Rothermel, R., 1983. How to Predict the Spread and Intensity of Forest and Range Fires USDA, Forest Service, Intermountain Forest and Range Experiment Station, General Technical Report INT-143, Ogden, UT.

Saglam, B., Bilgili, E., Dinc Durmaz, B., Kadiogullari, A.I., Kücük, O., 2008. Spatiotemporal analysis of forest fire risk and danger using LANDSAT imagery. Sensors 8, 3970-3987.

Salvador, R., Lloret, F., Pons, X., Pinol, J., 2005. Does fire occurrence modify the probability of being burned again? A null hypothesis test from Mediterranean ecosystems in NE Spain. Ecological Modelling 188, 461-469.

San-Miguel, J., Camia, A., 2009. Forest fires at a glance: facts, figures and trends in the EU. In: Birot, Y. (Ed.), Living with Wildfire: What Science Can Tell Us. EFI Discussion Paper, vol. 15. EFI, Joensuu, pp. 11-18.

Scozzafava, S., De Sanctis, A., 2006. Exploring the effects of land abandonment on habitat structures and on habitat suitability for three passerine species in a highland area of central Italy. Landscape and Urban Planning 75, 23-33.

Sebastian-Lopez, A., Salvador-Civil, R., Gonzalo-Jimenez, J., SanMiguel-Ayanz, J., 2008. Integration of socio-economic and environmental variables for modelling long-term fire danger in southern Europe. European Journal of Forest Research 127, 149-163.

Serra, P., Pons, X., Saurí, D., 2008. Land-cover and land-use change in a Mediterranean landscape: a spatial analysis of driving forces integrating biophysical and human factors. Applied Geography 28, 189-209. 
Silva, J.S., Rego, F., Fernandes, P., Rigolot, E., 2010. Towards Integrated Fire Management - Outcomes of the European project fire Paradox. In: European Forest Institute Research Report, vol. 23, 241 pp.

Sluiter, R., de Jong, S., 2007. Spatial patterns of Mediterranean land abandonment and related land cover transitions. Landscape Ecology 22, 559-576.

Taillefumier, F., Piégay, H., 2003. Contemporary land use changes in prealpine Mediterranean mountains: a multivariate GIS-based approach applied to two municipalities in the southern French Prealps. CATENA 51, 267-296.

Tanrivermis, H., 2003. Agricultural land use change and sustainable use of land resources in the mediterranean region of Turkey. Journal of Arid Environments 54, 553-564.

Tatoni, T., Magnin, F., Bonin, G., Vaudour, J., 1994. Secondary succession on abandonned cultivation terraces in calcareous Provence. I - vegetation and soil. Acta Oecologica 15, 431-447.

Thavaud, P. (Ed.), 2009. Guide pratique pour l'entretien des coupures de combustible par le pastoralisme. Réseau Coupures de combustible, vol. 12. Editions de la Cardère, Morières, $68 \mathrm{pp}$.

Thonicke, K., Venevsky, S., Sitch, S., Cramer, W., 2001. The role of fire disturbance for global vegetation dynamics: coupling fire into a dynamic global vegetation model. Global Ecology and Biogeography 10, 661-677.

Trabaud, L., Galtié, J.-F., 1996. Effects of fire frequency on plant communities and landscape pattern in the Massif de Aspres (southern France). Landscape Ecology $11,215-224$.

Turner, M.G., Dale, V.H., 1990. Modeling landscape disturbance. In: Turner, M.G., Gardner, R.H. (Eds.), Quantitative Methods in Landscape Ecology. SpringerVerlag, New York, pp. 323-351.

Turner, M.G., Gardner, R.H., Dale, V.H., O'Neill, R.V., 1989. Predicting the spread of disturbance across a heterogeneous landscape. Oikos 55, 121-129.

Vélez, R., 1990. Fire preventive silviculture in Spain. Revue Forestière Française 42, $320-331$.

Vélez, R. (Ed.), 2000. La defensa contra incendios forestales: fundamentos y experiencias. McGraw-Hill, Madrid.

Valette, J.C., Rigolot, E., Etienne, M., 1993. Intégration des techniques de débroussaillement dans l'aménagement de défense de la forêt contre les incendies. Forêt Méditerranéenne 14, 141-153.

Van Doorn, A., Bakker, M., 2007. The destination of arable land in a marginal agricultural landscape in south Portugal: an exploration of land use change determinants. Landscape Ecology 22, 1073-1087.

Van Eetvelde, V., Antrop, M., 2004. Analyzing structural and functional changes of traditional landscapes-two examples from southern France. Landscape and Urban Planning 67, 79-95.

van Leeuwen, W., Casady, G., Neary, D., Bautista, S., Allosa, J.A., Carmel, Y., Wittenberg, L., Malkinson, D., Orr, B.J., 2010. Monitoring post-wildfire vegetation response with remotely sensed time-series data in Spain, USA and Israel. International Journal of Wildland Fire 19, 75-93.

Van der Trol, C., Dolman, A.J., Waterloo, M.J., Rapsor, K., 2007. Topography induced spatial variations in diurnal cycles of assimilation and latent heat of Mediterranean forest. Biogeosciences 4, 137-154.

Van der Werf, G.R., Randerson, J.T., Collatz, J., Giglio, L., 2003. Carbon emissions from fires in tropical and subtropical ecosystems. Global Change Biology 9, 547-562.

Vasconcelos, M.J.P., Silva, S., Tome', M., Alvim, M., Pereira, J.M.C., 2001. Spatial prediction of fire ignition probabilities: comparing logistic regression and neural networks. Photogrammetric Engineering and Remote Sensing 67, 73-81.

Vazquez, A., Moreno, J.M., 1993. Sensitivity of fire occurrence to meteorological variables in Mediterranean and Atlantic areas of Spain. Landscape and Urban Planning 24, 129-142.

Vazquez, A., Moreno, J.M., 1998. Patterns of lightning-, and people-caused fires in peninsular Spain. International Journal of Wildland Fire 8, 103-115.

Vazquez, A., Moreno, J.M., 2001. Spatial distribution of forest fires in Sierra de Gredos (central Spain). Forest Ecology and Management 147, 55-65.
Vazquez, A., Perez, B., Fernandez-Gonzalez, F., Moreno, J.M., 2002. Recent fire regime characteristics and potential natural vegetation relationships in Spain. Journal of Vegetation Science 13, 663-676.

Vega-García, C., Chuvieco, E., 2006. Applying local measures of spatial heterogeneity to Landsat-TM Images for predicting wildfire occurrence in Mediterranean landscapes. Landscape Ecology 21, 595-605.

Viedma, O., 2008. The influence of topography and fire in controlling landscape composition and structure in Sierra de Gredos (central Spain). Landscape Ecology 23, 657-672.

Viedma, O., Melia, J., Segarra, D., GarciaHaro, J., 1997. Modeling rates of ecosystem recovery after fires by using Landsat TM data. Remote Sensing of the Environment $61,383-398$.

Viedma, O., Moreno, J.M., Rieiro, I., 2006. Interactions between land use/land cover change, forest fires and landscape structure in Sierra de Gredos (central Spain). Environmental Conservation 33, 212-222.

Viedma, O., Angeler, D.G., Moreno, J.M., 2009. Landscape structural features control fire size in a Mediterranean forested area of central Spain. International Journal of Wildland Fire 18, 575-583.

Viegas, D.X., 1998. Weather, fuel status and fire occurrence: predicting large fires. In: Moreno, J.M. (Ed.), Large Forest Fires. Backhuys, Leiden, pp. 31-49.

Viegas, D.X., Viegas, M.T., 1994. A relationship between rainfall and burned area for Portugal. International Journal of Wildland Fire 4, 11-16.

Vilà, M., Lloret, F., Ogheri, E., Terradas, J., 2001. Positive fire-grass feedback in Mediterranean basin woodlands. Forest Ecology and Management 147, 3-14.

Weatherspoon, C.P., Skinner, C.N., 1996. Landscape-level strategies for forest fue management. In: Sierra Nevada Ecosystem Project: Final Report to Congress, II: Assessments, Scientific Basis for Management Options. Centers for Water and Wildland Resources, University of California, Davis, Water Resources Center Report, vol. 37, pp. 1471-1492.

Wilson, A.G., 1988. Width of firebreak that is necessary to stop grass fires: some field experiments. Canadian Journal of Forest Research 18, 682-687.

Wittenberg, L., Malkinson, D., 2009. Spatio temporal perspectives of forest fires regimes in a maturing Mediterranean mixed pine landscape. European Journal of Forest Research 128, 297-304.

Xanthopoulos, G., 1998. Forest fires in Greece: past, present and future. Epikentra 6, 62-71 (in Greek).

Xanthopoulos, G., 2007a. Olympic flames. Wildfire 16, 10-18.

Xanthopoulos, G., 2007b. Forest fire policy scenarios as a key element affecting the occurrence and characteristics of fire disasters. In: Abstracts of the "IV International Wildland Fire Conference", May 13-17, 2004, Seville, Spain, p. 129. Full paper on $C D$ edition.

Xanthopoulos, G. 2007c. Forest fires in Greece: 10 years later. ETHIAGE Trimonthly Magazine of the National Agricultural Research Foundation, Athens, Greece, vol. 28, p. 6-9 (in Greek)

Xanthopoulos, G., 2008a. Who should be responsible for forest fires? Lessons from the Greek experience. In: Proceedings of the "II International Symposium on Fire Economics, Planning and Policy: a Global View", April 19-22, 2004, Cordoba, Spain. USDA Forest Service, Pacific Southwest Research Station, PSW-GTR-208, pp. 189-202.

Xanthopoulos, G., 2008b. Parallel lines. Wildfire 17, 8-20.

Xanthopoulos, G., Caballero, D., Galante, M., Alexandrian, D., Rigolot, E., Marzano, R. 2006. Forest fuels management in Europe. In: Andrews, P.L, Butler, B.W. (Eds.) Proceedings of the Conference on "Fuels Management-How to Measure Success", March 28-30, 2006, Portland, Oregon, USA. USDA Forest Services, Rocky Mountain Research Station, Fort Collins, CO. RMRS-P-41, pp. 29-46.

Zavala, M.A., Espelta, J.M., Retana, J., 2000. Constraints and trade-offs in Mediterranean plant communities: the case of holm oak-Aleppo pine forests. Botanical Review 66, 119-149.

Zedler, P.H., Seiger L.A., 2000. Age mosaics and fire size in chaparral: a simulation study. In: Keeley, J.E., Keeley, M.B., Fotheringham, C.J. (Eds.), Second Interface between Ecology and Land Development in California. U.S. Geological Survey Open-File Report 00-62, Sacramento, CA, pp. 9-18. 